\title{
Kentsel Kimliğin İnşası Bağlamında Toplumsal Hafıza ve Tarih Yazımı: Bartın Örneği
}

\author{
S. Yetkin IŞIK ${ }^{1 *}$, Ulaş Başar GEZGiN²。 \\ 'Doç. Dr., Antropoloji Bölümü, Bartın Üniversitesi, Bartın, TURKEY \\ ${ }^{2}$ Prof. Dr., Beşerî Bilimler Fakültesi, Duy Tan Üniversitesi, Danang, ViETNAM
}

\begin{abstract}
* Sorumlu Yazar / Corresponding Author: Sefer Yetkin Işık Bartın Üniversitesi, Edebiyat Fakültesi, Antropoloji Bölümü Bartın / TÜRKIYE E-posta: syetkini2009@gmail.com

Alındı/Received: 5 Kasım / November 2018 Düzeltildi/Revised: 25 Mart / March 2019 Kabul/Accepted: 28 Mart / March 2019 Erken Görünüm/Early View: 2 Nisan / April 2019 Yayımlanma/Published: 12 Haziran / June 2019
\end{abstract}

\section{$\ddot{O} z$}

Bu makale Batı Karadeniz kıyısında küçük bir kent olan Bartın’a ilişkin bir etnografik araştırmaya dayanmaktadır ve küçük bir liman kasabasının XIX. yüzyıldan XX. yüzyılın ortalarına kadar süren yaklaşık yüz yıllık ekonomik gelişiminin, 1980’lerden sonra küresel ölçekte değişen ekonomi-politikteknolojik koşulların etkisi altında yerel düzeyde de üretim ilişkileri, üretim tarzı ve üretim araçlarının dönüşme sürecinin günümüzde kentte yaşayanların anlatılarına nasıl yansıtıldığı hakkındadır. Resmi ve gayri resmi konumları işgal eden yerel aydınların Bartın'ın il olduğu 1991'den sonra giderek artan kent kimliği inşası olarak tanımlanabilecek entelektüel girişim ve çabaları kentin tarihi üzerine odaklanır ve ortak bir tarih ve kent imgesi oluşturmaya çalışılırken nelerin hatırlamaya değer olduğu, geçmişin hangi imgelerle hatırlandığ1 farklı mesleklerden, sınıflardan ve yaşlardan kentlilerin anlatımlarında bir ideolojik çeşitlilik oluşturmaktadır. Görüşmelerde ortaya çıkan, hatırlanmaya değer ve/veya anlamlı olana dair farklı yaklaşımlar, bir yandan sınıfsal ve eş zamanlı öte yandan kentin üretim ilişkileri ve tarzının dönüşümünü yansıtan, yani tarihsel/paradigmatik farklılaşmayı ortaya koymaktadır. Araştırmada, 19 Bartınlının tarihsel anlatıları bir araya getirildi ve kentsel imgelerin oluşturulması ve kimlik inşası bağlamında yorumlandı.

Anahtar Sözcükler: Bartın, kaptan anlatıları, toplumsal hafıza, kentsel kimlik, kentsel imge

\section{Giriş}

Tarihçi Kudret Emiroğlu, kentlerin adlarının anlamı ve kökeni hakkında yazdığı 1985 tarihli bir makalesini şu cümleyle bitirmektedir: "Halen doğum yeri anlamında kullanılan memleket sözcüğü ile hemşerilik anlayışı yaşam biçimimize gölgesini vururken, yaşanılan mekânların biçimlenişi ve belirleyişi sorulmadan kalmaktadır" (Emiroğlu, 1985: 46). Yeni tarihçilik yaklaşımının izleyicilerinden olduğu anlaşılan bir başka yazar ise, 2001'de yayımlanan makalesinde insanmekân ilişkisinin tarih yazımında göz ardı edildiğinden yakınırken şöyle demektedir:
Collective Memory and Historiography in the Context of Construction of the Urban Identity: The Case of Bartin

\begin{abstract}
This article is based on an ethnographic research on Bartm, a small city on the West Black Sea coast. In the article, how a century of economic development of a little port town and its conditions prior to 1980 influence the local collective memory of Bartin is investigated. As has been pointed out in the studies on collective memory, questions such as what is memorable, or which historical images are remembered and registered can be answered with reference to actors' ages, classes and/or occupations. In this research, we found that different approaches about what is memorable or meaningful are based on social stratification, on the one hand and the city's production and transformation process, that is to say, economic-historical factors on the other. In the research, narratives of 19 Bartmese were collected and interpreted in the context of the construction of the urban identity and the urban self-image.
\end{abstract}

Key Words: Bartm, captain narratives, collective memory, urban identity, urban images

Tarihi olaylar mutlaka bir coğrafi ya da beşerî mekânda gelişirler. Bu mekân ise bir caddedir, mahalledir, şehirdir veya bir ülkedir. Böyle olmasına rağmen çoğu kez insan-mekân ilişkisinin geri plana itildiği ve olayların geçtiği tarihsel mekânların olayların geçtiği bir dekor düzeyine indirgendiği görülüyor. Oysa insanla yaşadığı mekân arasında çift yönlü bir etkileşim bulunmaktadır. İnsan yaşadığ1 mekânı biçimlendirirken çoğu kereler mekân ya da coğrafya da insanı belirleyebilmektedir. Ülkemiz tarihçiliğinin bugün eksik yönlerinden birisi de mekân bilgisinin yetersizliğidir (Sarıŏlu, 2001: 334). 
Mekân-toplum-kültür diyalektiğini göz ardı eden tarihçilik anlayışına ek olarak sosyal bilimcilerin 1980 sonrası veya post-Sovyet dönemde postmodernizmin saldırılarına karşı da kendi konumlarını savunmak durumunda kaldığını biliyoruz. Antropolog Özbudun (2014),postmodernizmin bilimive bu arada antropolojiyi, herhangi bir anlatıya dönüştürme yönündeki gayretlerini eleştirirken antropologlara "varoluş ile toplumsal tahayyül, beden ile zihin, pratik ile düşünce, yapma ile bilme, sınıf ile kültür arasındaki sahte düalizmleri ilga edip aralarındaki, ancak birlikte var olmalarını sağlayan ya da onları Janus'un iki yüzü kılan diyalektik ilişkiyi açığa çıkartan" bir yaklaşımı benimsemeyi önermektedir. (Özbudun, 2014: 7). Bu araştırmaya bütün bu -ve burada aktarılmayan benzeri birçok- eleştiri ve önerilerden yola çıkıldı. Çevre ve üretim ilişkileri ile anlam sistemleri arasında tutarlı ve açılanabilir ilişkiler olduğunu varsayan maddeci antropolojik bir çerçeveden hareketle, Bartın'da kültürün maddi (doğal ve yaşamsal çevre, geçim sağlayıcı öğeler) katmanıyla simgesel (anlam ve değerleri içeren) katmanı arasındaki ilişkilere bakıldı.

Makale yazarlarından biri Bartın'da yaşamaya başladıktan iki yıl sonra, gündelik konuşmalarda kentin geçmişine dair bilgiler edinmiş, yine bu konuşmalarda kentte 1980'lere kadar kentte nehir-deniz taşımacilığ1 yapıldığ1, bu ahşap gemilerde kaptanlık yapan son üç kişinin hayatta olduğu bilgisini edinmiştir. Makale yazarları, nehir-deniz taşımacılığının 1940-1980 y1llar1 arasındaki döneminin sözlü tarihini yapmak üzere bu kaptanlarla, görüşme kararı almıştır. Ancak sözlü tarih yapmaya dönük görüşmeler çeşitli nedenlerle (görüşülen kaptanların 90lı yaşlarda oluşu ve pek çok şeyi hatırlamadıklarını veya emin olamadıklarını söylemeleri, kaptanlardan bazılarının da işitme sorunları oluşu ve birinin de çok daha ciddi hastalıklarla mücadele ediyor oluşu gibi) verimsiz geçmiştir. Bunun üzerine araştırmacılar da görüşmeleri kaptanlarla sınırlandırmaktan vazgeçip kaptanlık yapmış kişilerin çocukları veya gemilerde çalışmış yardımcıları, denizcileri ve konuyla ilgili bilgisi, tanıklığı olan kent halkından herkesi araştırma sürecine dâhil etme kararı almışlardır. Böylece araştırma, toplumsal hafıza ve kent kimliği ilişkisi şeklinde esnek bir çerçeve içinde yürütülmeye başlandı. Odaklandığımız bir başka genel sorun ise, yerel yazılı kaynaklarda, Belediye'nin düzenlediği kamuya açık alanlarda çok vurgulanan bölgenin denizci geçmişinden sözlü kültüre, kültürel hafizaya nelerin miras kaldığıydı. Bir diğer deyişle, doğal ve yaşamsal çevre ile ilişkinin ve bu temel üzerinde ilerlemiş olan üretim-tüketim ilişkilerinin kültüre, anlamlar ve simgeler düzlemine hangi biçimlerde yansıdığını soruşturduk.

Yerel yazılı kaynaklarda (yerel gazete köşelerinde kentin geçmişine dair bilgiler veren yazarların -genellikle bu yazıların derlenmesinden oluşmuş- kitapları; Belediye
Başkanlığ1 tarafindan yayımlanmış diğer yerel kaynaklar) birçok meslekten kişiye yer verildiği görülmektedir. Kolektif hafiza bakımından kentin cadde ve sokaklarına verilen isimler de oldukça dikkat çekicidir. Bu isimlerin kentin tarihinde önemli rol oynamış figürler olduğu söylenmektedir ve bunlardan bazıları birkaç dönem üst üste belediye başkanlığı yapmış Kemal Samancıoğlu gibi kişilerdir. Öte yandan pek çok cadde ve sokak adının gerekçesi yalnızca “eski ve köklü aileler"e mensup olmak şeklinde açıklanmıştır ve görüşmecilerden bazıları yarı alay yarı öfkeyle bu isimlerin çoğunu tanımadıklarını ve belediye basskanlarının isim verme uygulamasını siyasi amaçlara alet ettiğini ifade etmiştir. Burada bizim açımızdan dikkat çekici olan hem yerel tarih yazarlarınca kaleme alınan kitaplarda ve yazılarda hem cadde ve sokak adları arasında kaptanlar ve denizcilere nadiren yer verilmesidir. Bu eksiklik veya ihmal, bizi toplumsal hafıza sorununa yöneltti ve bugünü yaşayanların geçmişi yeniden kurgularken hangi olay ve figürleri önemli ve değerli gördükleri konusunu araştırmak için başlangıç noktası oldu. Böylece sinıf aidiyeti ile kente aidiyetle tanımlanan kimlik arasındaki uyuşmalar ve çelişkiler, kolektif hafıza ve hafizanın çoğulluğu gibi sorunlara odaklandık. Dolayısıyla, bu araştırmanın amacı, kent kimliği ve kente dair imgeler oluşturulurken başvurulan toplumsal hafiza ile toplumsal siniflar arasindaki ilişkilerdir.

\section{Kimlik, Kent Kimliği ve Kentsel İmgeler}

Kimlik, bir kişinin veya bir topluluğun kim olduğunun bilgisi, kim olduğuna ve kimlere/nereye ait olduğuna dair bilincidir. Kimlik hem bireye (psikolojiye) hem toplumsallı̆a (sosyolojiye) gönderme yapan bir ilişkiselliktir. "Kimlik sorununun ortaya çıktığ1 ortam, insanın "kendisini ne olarak/neye dayanarak tanımladığı" ya da "kendisini diğerlerinden ayırt eden özelliklerin neler olduğu" sorularına dayanır. Yani, özetle, kişinin "mensubiyet" (attachment) ve "ait olma" (belonging) konusundaki başvuru çerçeveleri, kimlik "tutunumu"nu (cohesion) sağlayan dayanaklardır.” (Aydın 2003: 469477). Aydın'a göre “"kimlik', 1980’lerin başlarında sosyolojinin ve sosyal antropolojinin yorumsal ve teknik söz dağarcığına girmiştir. 1940’lardan önce kavram bilinmiyordu. Son kırk-elli yıl içinde kavram göz ardı edilemeyecek bir teknik terim haline geldi." (Aydın, 2003: 473-4). 1980 sonras1 döneme dair inceleme ve analizlerin postmodernizm ve küreselleşme başlikları altında yoğunlaştığını dikkate alarak kimlik konusuna yoğun ilgiyi de küreselleşmenin kültürleri birbirine benzeten, homojenleştirici etkisine karşı yerel bir tepki olarak da yorumlayabiliriz (ve genel olarak bu şekilde yorumlanmaktadır). Yanı sıra Batı'nın büyük kentlerine dünyanın her yerinden akan göçmenler bu kentlerde getto mahalleler oluştururken kendi 'arada' 
konumlarının kimlik arayışını, kimlik (özellikle etnik kimlik) konusundaki duyarlılı̆̆1 arttırdığ1 söylenebilir. Bauman ise şu yorumu yapmaktadır:

\begin{abstract}
Otuz kırk yll öncesine kadar "kimliğin" sosyolojik düşüncede merkezi bir yere sahip olmayıp felsefi düşüncenin nesnesi olarak kaldığını hatırlayacak olursak, bu konunun sosyoloji için gerçekten bir sorun ve güçlük olduğunu daha iyi anlarız. Günümüzde "kimlik" halkın en önemli gündemi, herkesin zihninde ve dilindeki acil çözüm bekleyen konudur. Onunla karşılaşacak kadar yaşamış olsalardı sosyolojinin kurucu babalarının dikkatini çekecek olan şey, kimliğin kendisinden ziyade ona karşı gelişen bu ani ilgi olurdu. Muhtemelen Martin Heidegger'den hareketle, bir ipucuna ulaşırlardı (fakat bu ipucu sunulduğunda bile çoktan bu dünyadan göçmüşlerdi): Şeyler ancak ortadan kaybolduklarında, işe yaramaz hale geldiklerinde, saçmalama, onları araştırmamızın odağına koyma ya da tefekkür dünyamıza katma eğilimindeyiz (Bauman, 2017: 28).
\end{abstract}

Bauman (2005:187) kimlikilegeçmiș (nostaljik merak veya kişinin belirsiz konumu nedeniyle aidiyet bağları bulabilmek amacıyla başvurduğu geçmiş) arasındaki bağ1 şöyle formüle etmektedir: "kimlik, toplulukların mezarlığında filizlenir, ama ölüyü diriltme vaadi sayesinde gelişip büyür." Bu ferasetli ifade günümüzde dünyanın büyük metropollerinde oluşmuş farklı etnik/etno-dinsel toplulukların kimlik ilgisini açılamaktadır. Bartın'da kentleşme sürecinin hızlandığ1 XIX. yüzyılın aynı zamanda çözülen Osmanlı İmparatorluğu'nun birçok bölgesinden gelenlerin olduğu kentteki lakaplardan - bu lakaplardan birçoğu soyadı kanunu sonrasında soyadı olarak alınmıştır- anlaşılmaktadır: Gürcüler, Moralılar, Tunalılar, Kırımlılar, Safranbolulular, Üsküdarlılar gibi... İronik olarak bu lakap ve soyadları gelenlerin geldikleri yerleri, kökenlerini unutmamak amacina hizmet ederken, sonraki kuşakları buluşturabilecek ortak bellek herkesi Bartın kent kimliğinde buluşmaya, yani kökenleri unutmaya zorlamaktaydı.

\section{Bellek ve Sözlü Tarih}

Kolektif hafızanın bir araştırma alanı olarak -Türkiye'de 1990'lardan itibaren- önem kazanmas1, kimliklere yönelik ilginin artışını gözlemlediğimiz konjonktürel çerçevede gerçekleşti. Kökleri Annales Okulu içinde bulunan toplumsal tarih, zihniyetler tarihi, kültür tarihi vb. araştırmalar bu dönemde çoğalırken bu yeni tarihçilik anlayışı içinde belgelere (özellikle resmî belgelere), arşivlere dayalı tarihçiliğin eleştirisi ve alternatif yöntem arayışları da gündeme geldi. Tarihsel antropoloji ve sözlü tarih gibi sıradan insanın geçmişine odaklanan, olaylara değil de olayların hafizalarda bıraktığı izlere odaklanan çalışma alanlarını da bu değişimin bir parçası sayabiliriz. Konu üzerinde düşünenlerden biri olan Paul Ricoeur (2014: 103-4) ise çağdaş tarihçiler arasında olayın kendisine değil bu olayları deneyimleyenlere, hatırlayanlara ve hatırlanma biçimlerine odaklanan bafiza taribçiliğinin yeni bir çalışma konusu haline geldiğine dikkat çekmektedir [vurgu bana ait].

Kolektif hafiza veya toplumsal hafiza kavraminin müellifi, Durkheim ve Bergson'un öğrencisi olmuş Maurice Halbwachs, hafizanin her zaman toplumsal bir çerçevesi olduğunu göstermeye çalışır. Hatırladıklarımız ne kadar kişisel olursa olsun, gerçekte toplumsal bir bağlamda oluşmuştur. Ona göre "hatırlamakta en az zorlandığımız olgular ve kavramlar, en azından bir ya da birkaç ortam için, ortak alana aittir. [...] çok tuhaf ve çelişkili görünebilse de zihnimizde en zor canlandırdığımız hatıralar, yalnızca bizimle ilgili olan, bizim de bir şekilde kendimizden ve diğerlerinden gizlediğimiz, en mahrem parçalarımızı teşkil edenlerdir" (Halbwachs, 2017: 37). Halbwachs, tarih ve hafiza ayrımına ve hafızanın çoğulluğuna da dikkat çekmiştir.

Kolektif hafıza çalışmalarında sözlü kültürler ve yazılı kültürler arasındaki başlıca ayrım olan hatırlama teknikleri/teknolojisi kritik önemdedir. Sözlü kültürlerde ritimli-uyaklı sözler, kalıp sözler, ritüeller, mitler, sürekli tekrarlanarak kuşaktan kuşağa aktarılır ve en önemli kayıt aracı insanların belleğiyken, okuryazarlı̆̆ın yaygınlaşması, yazılı kültürün ortaya çıkışıyla bu durum değişmiştir. Günümüzde tartışma konusu olan hafiza-tarih (yazımı) çelişkisi veya karşıtlığının kökeninde bu dönüşümün belirleyici olduğu söylenebilir. Pierre Nora'nın resmi tarih ile bellek çelişkisi üzerine yürütülen tartışmalarda, en etkin isimlerden biri olduğunu söyleyebiliriz. Nora'ya göre bellek ve tarih amansız bir karşıtlık içindedir. Bellek "sürekli evrim halindedir" ve "manipülasyonlara yatkın, ard1 arkas1 kesilmeyen deformayonlarının farkında değildir". Buna karşlık "tarih, entelektüel ve seküler bir üretim olduğundan analiz ve eleştiriye açıktır... tarihin temelinde, kendiliğinden hatırlamaya karşıt, kritik öneme sahip bir söylem vardır. [...] Tarih bellekten hep şüphe eder ve asıl misyonu onu bastırmak ve yok etmektir" (Nora 1989; akt. Wertsch, 2015: 15960). Nora (1989) tarihin, modern toplumların bugüne dair umutsuzca değişim arayışlarının sonucu olarak geçmişi düzenlemek ihtiyacından doğduğunu iddia eder. Kaybolmakta olan şimdinin saklanması ihtiyac1 ve bu konudaki hassasiyetin getirdiği baskının, geleneklerin, adetlerin ve atadan kalanın tekrarının içinde hâlâ canlı olarak yaşayan deneyimin yerini aldığını belirtir. Çünkü benlik bilinci, hali hazırda olmuş olanın göstergeleri içinde ortaya çıkmaktadır. Gerçek hafıza ortamlarının ortadan kalkmasıyla, geçmişten kopan bilincin, geçmişe dair hafızayı yeniden uyandırma ve onu kristalleştirerek cisimleştirme çabası olarak "hafıza mekânları" (lieux 
de mémoire) kurar modern insan. Böylece geçmişin devamlılı̆̆1 sağlanacaktır (Nora 1989, akt. Uslu, 2017: 45).

\section{Bartınlıların Kentlerine Dair Öz-imgeleri}

Toplumlar öz imgelerini hayali olarak oluştururlar ve yarattıkları hatırlama kültürü ile bu imgeyi kuşaktan kuşağa iletirler. (Assman, 2018: 25). Bartınlılar kentlerinin (Amasra ile birlikte) tarihi eskilere uzanan bir kent olduğunun bilincinde olarak bu tarihin kentin yararına ve kentlileri birleştirici bir unsur olarak işlenmesi gerektiğini düşünürler (kentin resmi ve gayri resmî kurumları ve yerel aydınları, insanları bu yönde sevk etmeye çalışır). Assman, yukarıda anılan eserinde iletişimsel bellek ve kültürel bellek olmak üzere iki tür bellek kategorisi önerir. "İletişimsel bellek yakın geçmişe ilişkin anıları kapsar. Bunlar kişinin çağdaşları ile paylaştı̆̆ anılardır.” (Assman, 2018: 58). Bu tür belleğe yönelik sözlü tarih yöntemiyle yapılan araştırmalar olduğunu not düşen Assman, kültürel belleğin, kurumlaşmış bir bellek tekniği olduğunu, bayramlar, törenler, mitler gibi hatırlama figürlerini içerdiğini, kültürel belleğin toplumsal kimliği kuran bir rolü olduğunu anlatır. (Assman, 2018: 60-61).

Burada ele alınan soruna, Assman'in oluşturduğu kavramsal ve kuramsal çerçeveden yaklaşarak araştırmamıza konu bellek türünü iletişimsel bellek olarak tanımlayacağız. Kimlik oluşturma çalışmasının kentleşme süreciyle paralel ilerlediğini tarihsel kayıtlardan izleyebildiğimiz Bartın'da, “ben"lerden "biz" oluşturma çabasında özellikle ortak tarihin/ortak belleğin üzerinde çalışıldığ1 görülmektedir. Kentsel imgenin oluşturulmasında geçmişin oldukça başat bir rol ve işleve sahip olduğunu, şu verilere dayanarak söyleyebilmekteyiz:

(i) Kent meydanında, önemli kamusal mekânlarda (şehir merkezindeki parkta) kentin tarihine dair fotoğraflar yer almaktadır.

(ii) Kentin yerel gazetelerinde geçmiş dönemlerin kişi ve olaylarına, yerel geleneklere sik sik yer verilmektedir.

(iii) Kentte yaşayan yerli yazarlar tarafindan, yine kenti konu alan kitaplar Belediye Başkanlığ tarafindan yayımlanmaktadır ve bu kitapların çoğu kentin tarihine dairdir. Günümüzde Bartın'da -toplam sayıyı kesin olarak bilmesek de- tanıdığımız, eserlerini gördüğümüz kentle ilgili (yazılı, görsel, işitsel) arşivler oluşturan, kitaplar veya gazete yazıları yazan on beş-yirmi kişi vardır (bu gözlemler yalnızca Bartın'da yaşayan ve kent hakkında çalışmalar yapıp yayınlayanları kapsamaktadır. Tezler ve akademik araştırmalar dikkate alınmamıştır).

(iv) Kentlilerin ortak çabalarıyla kent müzesi kurulmuştur ve benzeri projeler planlanmaktadır (mevcut belediye başkanının vaatleri arasında kent bellek merkezi, denizcilik müzesi ve Kemal Samancioğlu Etnografya Müzesi'nin yeniden tasarlanıp düzenlenmesi gibi vaatler yer almaktadır).

(v) "Kentin eski ve köklü aileleri” olarak bilinen kişilerin adları/soyadlarının sokak ve caddelere verilmesi uygulamas1 yaygindir. Bunun gibi uygulamalarla kentsel bellek ile aile tarihleri/ hatıraları sürekli ilişkilendirilmekte ve simgesel önem kazanmıs bu "eski/köklü" ailelerin isimleri toplumsal bellekte canlı tutulmaktadır.

\section{"Bartın deresi, altın deresi": Toplumsal Hafizada Irmak}

Nora, anılan eserinde "hafıza mekânları"nı şöyle tanımlar: İnsanların iradesiyle ya da zamanın işleyişiyle herhangi bir topluluğun ortak hafizasına ait simgesel öğe haline getirdiği maddi ya da fikri düzendeki her anlamlı birim (Nora, 2006: 171). Yine yazara göre,

\begin{abstract}
Hafiza, her zaman yaşanan gruplar tarafindan üretilen yaşamın kendisidir. (...) Anımsama ve unutma diyalektiğine açık, onlanın sürekli biçim değiştirmelerinden habersiz, her türlü kullanımlara ve el oyunlarına karşı çok duyarlı, uzun belirsizliklere ve ani değişimlere elverişlidir ve devamlı gelişim halindedir (...) sadece onu güçlendiren ayrıntılarla uyuşur, çünkü duygulara dayalı ve sihirlidir (...) Hafıza, hatırayı kutsallaştırır (...) doğası bakımından değişik ve sınırsız, kolektif, çoğul ve bireyselleşmiştir (...) Hafıza somuta, uzama, harekete, imgeye ve nesneye kök salmıştır (Nora, 2006: 236-37).
\end{abstract}

Burada, Bartınlıların ortak hafizasında merkezi bir mekân olan İskele (faal olduğu dönemdeki adiyla Tahmil Tahliye İskelesi) ve bir zamanlar tersanelerin yer aldığı Yalı'nın (Bartın Çayı'nın yanı başında uzanan cadde) geçmişi ortak bir kimliğe ve tarihe aidiyet için geri çağırmanın mekânı oluşunun yanı sıra, Bartın Çayı üzerinde gerçekleşen taşımacıllk ve yolculukların da, artık sürdürülmeyen zanaatların, yapılmayan yemeklerin anılmasından yola çıkarak, 1980 sonrası Türkiye'nin etkisine girdiği tüketim kapitalizmi ve tüketim kültürüne karş1 bir tepki olduğu da söylenebilir. Günümüzde Bartın kenti için temsil değeri taşıyan az sayıdaki eski ahşap evler, beton blokların arasında kaybolmakta, bir zamanların zengin kuş çeşitliliğine ev sahipliği yapmış olan büyük bahçeler yok edilip yerlerine apartmanlar, otoparklar, dükkânlar inşa edilmekte, kısaca piyasa mantığının dayattığ rasyonalite, kolay kazanç hırsı, tarihsel mekânları dönüştürmekte ve orta yaşın üzerindeki Bartınlıların kendilerini özdeşleştirdikleri anlamlı geçmişlerini istila etmektedir. Kültürel unutma, 
çevrenin yıkımına bağlı olduğu kadar, çevrenin sadece tüketim nesneleriyle kuşatılmış olmasına da bağlıdır (Connerton 2009, akt. Tuğrul 2014: 31).

Ortak bellekte 1rmak, hem bayramlarda (geçmiş yıllarda Bartın için son derece önemli olmuş olan Hidrellez ve Denizciler Bayrami) hem tarihi anlatılarda kentlilerin öz-imgesinde önemli bir öğe oluşudur. Bartın Çayı toplumsal hafiza ve kent kimliği kurgusunda, Antik Yunan dönemi kaynaklarına kadar uzanan geçmişiyle ve orta yaş üstündeki Bartınlıların özlemle andıkları yakın tarihe dair mutlu, renkli anılardaki rolüyle merkezi bir rol oynamaktadır. İlk görüştüğümüz kaptanlardan biri, kentte kullanılan bir kalıp sözü aktarmıstı: "eskiden 'Bartın deresi, altın deresi' derlerdi.' Buradaki altın sözcüğünün Bartın Çayı'na verilen değeri mi ima ettiği yoksa ırmağın kentin zenginleşmesinde, tüccarların yüzlerce kişinin geçiminde oynadığı rolü mü işaret ettiği belirsizdir. Ancak ikinci olasıllğın daha güçlü olduğu söylenebilir. Bu tahmin, daha sonra göstereceğimiz gibi, kentin tarihinde -dolayısiyla da kente dair imgelerdenehir-deniz ulaşımının ve bu yolla yapılan ticaretin/ tüccarların indirgenemez önemine dayanmaktadır.

Bartın'ın tarihi bir kent olduğu' görüşmeler sırasında sıkça vurgulanan, bu bakımdan kente dair ortak imgeler arasında belirgin bir yeri olan bir nitelik. Tarihi kent vurgusunun görüşmelerde rastlanan sıklığının en önemli sebeplerinden biri, başta belediye olmak üzere kentin temsilcilerinin, aydınlarının, derneklerin vb. bu yerel yayınlarda sık sık tarihi ve kültürel mirasa vurgu yapmasıdır. Bartın'da yazarlar, aktivistler ve en genel ifadeyle okuryazarlar olarak adlandirilabilecek siniftan figürlerce yürütülen ortak bir hafiza oluşturma veya kentlileri ortak anlamlarda buluşturma gayreti, öncelikle farklı çıkar ve motivasyonlara sahip kişileri birleştiren ortak bir kimliğin keşfine davet eder. Toplumda farkındalık yaratmak için, herhangi bir geçmişin seçilmesi yeterlidir. Bu geçmiş, duyguları yönetmeli, insanları eyleme teşvik etmeli ve algılanmalıdır; kısaca, sosyokültürel bir eylem modu olmalıdır (Confino, 1997; akt. İnce, 2010: 12). Bartın, Taribi Kentler Birliğ̨ nin üyesidir ve Bartın ve Amasra belediyelerinin yanı sıra ÇEKÜL Vakfı gibi, Bartın Platformu gibi dernek ve sivil toplum kuruluşları da kentin tarihi kültürel mirasını ve doğal çevresini korumaya yönelik etkinlikler yapmaktadır. Dolayısıyla bu dernek ve benzerlerinin etkinlikleri " tarihi kent" vurgusuyla ortak bilinci sürekli uyanık tutmaktadır. Tarihi kent ifadesine internet sayfalarinda/bloglarda ve kent hakkında yazılmış kitaplarda sıkça rastlanır.

Yerel tarihi konusunda yazmış olan yazarlardan biri olan Erkan Aşçıŏlu (2011), kentin 1400’lerden itibaren, yani henüz bir köyken nehir -deniz ticareti nedeniyle köylülerin ürettikleri çeşitli tarımsal-hayvansal ürünleri -muhtemelen 1rmaktan içeriye kadar giren gemilerden inen denizcilere- sattıkları bir pazar yeri olduğunu yazmaktadır. Öte yandan bu tür tarihler kesinlikten uzak olsa da XVIII. yüzyıl, genel olarak Osmanlı ekonomikpolitik koşullarının, özellikle de Karadeniz bölgesinin liman kasabalarının ekonomik ve sosyal yapisının hızla dönüştüğü bir dönemdir. Ordu tarihi örneğinde ${ }^{1}$ konu hakkında araştırma yapmış olan Ekinci (2016), Karadeniz'de bu dönemde hızlanan kentleşme sürecinde âyan ve eşraf sınıfinın merkezi otoriteye karşı daha güçlü ve bağımsız hareket etme kabiliyetinin artışına ek olarak deniz ticaretinin ve bu arada informel ekonomik faaliyetlerin artışının rolüne dikkat çekerek şöyle yazar:

Diğer bir husus da dikkatlerden uzak küçük iskelelerin gayrı resmi ticarete (karaborsa, kaçakçıllk) daha uygun bir zemin teşkil etmesidir. Bu kaçak ticaretin küçük iskeleleri canlandırdığ1 açıktır. On dokuzuncu yüzyıla kadar Doğu Karadeniz kı1 kesiminde iskele yahut Pazar yeri olarak kayitlarda adlarına rastlanan küçük yerleşmelerin birçoğu bu son asırda bazen hızlı bazen de yavaş seyir izleyerek zamanımıza, köy olmaktan çıkmış, yerleşmeleri iyice sahile kaymış şehir ve kasabalar olarak ulaşmıştır. (Ekinci, 2016: 110-111).

Pek çok kaynakta incelendiği gibi, geleneksel Osmanlı mali-ekonomik-askeri sistemi 16. yüzyıl ortalarından itibaren bozuldu ve tımarlı sipahileri işsiz bırakan, taşrada yeni zenginlerden oluşan eşraf ve âyanı güçlendiren yasal düzenlemeler birbirini izledi. Yeni sistemin esası, süre gelen iç ve diş savaşlar iççin ihtiyaç duyulan paranın hızlı teminini sağlamaktı. Bu öncelik, merkezin/sarayın taşra muktedirlerine sürekli taviz vermesini (ki, taşra egemenleri yüzlerce asker besleyecek duruma geldiler ve savaşlarda asker toplamak gibi rolleri nedeniyle de merkezi hükümetin muhtaç olduğu güçlere dönüşmüşlerdi) gerektirdi (bkz. Reyhan, 2000; Özkaya 2008; Ekinci 2013; Özkaya 2014). 18. yüzy1la gelindiğinde başka kentlerde olduğu gibi (örneğin Ankara'da Hollandalı tiftik tüccarlarının varlığında olduğu gibi), Karadeniz liman kentlerinde de ulus aşırı ticari sistemle teması olan eşraf ve âyan, geleneksel Osmanlı toplumsal yapısında olmadığı söylenen bir kentsel orta sınıfı oluşturmaktaydı. XIX. yüzyılda hızlanan Batılılaşma reformları, en önemlisi de Tanzimat Fermanı olan hukuk düzenlemeleri, yerel sermaye sahiplerinin (önünü açtı. Uluslararası sermaye ile yerli tüccarlar/mal sahipleri arasinda aracilik rolü üstlenen gayrimüslim tüccarlar başta olmak üzere burjuva sınıfi güçlendi. ${ }^{2}$ Bir zamanlar devletten kiraladıkları veya

1 Trabzon'un aynı dönemdeki dönüşümü açısından yararlı bir tarihsel antropolojik araştırma, Michael E. Meeker (2005) tarafindan yayımlanmıştır.

${ }^{2}$ Yirminci yüzyılın başında birçok Osmanlı aydını, Türk/Müslüman bir burjuvazinin olmayıșından yakınmaktaydı. Birinci Dünya Savaşı sirasinda ve sonrasinda izlenen politikalar (tehcir, mübadele) 
vergilerini topladikları arazilerin sahipleri durumuna gelen mültezim, mütesellim, müsellim, voyvoda gibi adlarla bilinen sınıf, toprakların mülkiyetine sahip oldu. Dünya kapitalizmiyle bütünleşme sürecinde de bu sinıflar hem ekonomik hem kültürel sermayenin taşrada birikmesinde rol üstlendiler. Bartın bu tarihi dönemeçte İstanbul'a, Köstence, Kırım gibi önemli limanlara yakınlığı nedeniyle ve zengin orman kaynakları (şimşir ağacı, gemi yapımı ve maden direği için uygun ağaçlar, kereste üretimine elverişli ağaçlar) sayesinde hızla gelişti.

Birinci Dünya Savaşı'nın ve bu sırada başta Rusya olmak üzere Karadeniz ülkelerinde meydana gelen devrimlerin, alt üst oluşların ve sonunda 1929 ekonomik bunalımının Bartın ekonomisini etkilememesi düşünülemezdi. Ancak Zonguldak Ticaret ve Sanayi Odası'nın rapor niteliğindeki yayını, 1933'te şu bilgileri gururla veriyordu: "Bartın mintıkasinda 923 senesinde (315) ve halen (521) yelkenli vardir. [...] on sene zarfinda artan? Mintakasında (986) motör yapılmıştır. Bartın tüccarı bu motörlerle Karadeniz ve Marmara'nın bütün ve Akdeniz'in baz1 iskelelerile münasebeti ticariyede bulunmaktadırlar." (ZSTO, 1933: 208-9). Oysa bu yıllar, yukarıdaki küresel etkenlere ek olarak Zonguldak ile Ankara'nın Bartın'ı dışarıda bırakacak bir demiryolu hattıyla birleşmesinin de etkisiyle Bartın'ın ekonomik durgunluk yaşadığı yıllardı. 1941'de basılan kitabında Samancioğlu'nun 1935 yılı nüfus sayımına ve Ticaret ve Sanayi Odası kayıtlarına dayandırdığı verilere göre, "Bartın'da ev, resmi ve umumi binalar sayıs1 1944; dükkân, mağaza ve atölyelerin sayısı 1066 ve yap1 yekûnu [toplam1] 3010'dur.' Sevük (2014: 226), 1936'da kentte o yıllarda ev olmayan yapıların sayısını bin yüz olarak verip, şaşırtıcı "iki eve bir dükkân” oranının kereste fabrikalarından yapılan kereste ihracatının durmuş olduğu kendi zamanının değil, geçmiş yılların gerçeğini yansıttı̆̆ını, yani kasabadaki zenginliğin bir önceki yüzyılın yoğun nehir-deniz taşımacillğııın ürünü olduğunu ifade etmektedir. Kent merkezinde, bugünkü adıyla Tersane caddesinde 1966'ya kadar üretime devam eden en az 4 tersane bulunmaktayd1 (Kapısuyu'nda son ahşap gemi 1979'da yapıldı). Kent merkezi dışında, Karadeniz kıyısında yani Tekkeönü, Kapısuyu ve Kurucaşile'de de tersaneler vardı (Bartın dışındaki birkaç tersanede günümüzde de tekne ve yat üretilmektedir). Kentin kereste ihracatına, yakın bölgelerden getirilip limandan ihraç edilen veya limana getirilip karayoluyla bölgenin yakın yerleşim yerlerine ulaştırilan ürünlerin taşındığı nehir-deniz taşımacıllı̆ına

sonrasında örneğin Zonguldak gibi bir liman kentinde, 1919-1922 yılları arasında ticaret odasına kayıtlı tüccarlara dair aşağıdaki veriler değişti: birinci sınıf: Türk 2/gayri Türk 9, ikinci sınıf Türk 18/gayri Türk 26, üçüncü sinıf Türk 8/gayri Türk 45, dördüncü sinıf Türk 12/gayrı Türk 160. (Zonguldak Ticaret ve Sanayi Odas1, 1933, s. 56-59). ve gemi üretimine borçlu olduğu bu refah, 1930’larda Ankara-Zonguldak arasında demiryolu inşasıyla -son bulmasa da- önemli bir darbe alır. Demiryolunun Bartın'a kadar uzatılmamasinin, hafizalarda derin izler bırakmış bir mesele olduğu anlaşılmaktadır. ${ }^{3}$ Ardından karayolları geliştirilir ve karayolu taşımacıllọ̆ maliyetleri, gemi sahiplerinin rekabet edemeyeceği kadar ucuzlar. Son olarak Türkiye'de de gemi teknolojisi ahşap gemileri demode k1lacak kadar modernleşir ve sac gemiler kullanılmaya başlanır. Böylece, Bartın tarihini üç döneme ayırabiliriz: Kentin doğal kaynakların işlenmesine ve coğrafi avantajlara dayanan bir "tarih öncesi", ulusal ve uluslararası piyasaya açı bir ticari kapitalizmle yaratılan "tarih sahnesine çıkış" evresi (bu evre 1980'lerde son bulur) ve son olarak 1980 'lerden sonra bu kez kent kimliği inşası ve kentsel imgenin üretimine dayanak olmak üzere incelenmeye, üzerine düşünülmeye başlandığ1, günümüzde de sürmekte olan "geçmişi tarihe dönüştürme" döneminden söz edebiliriz.

Bunlardan başka, günümüzde de ünlü bir tatil beldesi ve tarihi bir kent olan Amasra'nın 1960'lara, hatta 1970'lere kadar bölgenin tek tatil beldesi olduğu anlatılmakta, ünlü sanatçıların, örneğin Zeki Müren'in bile tatil için Amasra'ya geldiği, Kızılkum plajlarında birçok Yeşilçam filminin çekildiği anlatılmaktadır. (Görüşmeci V， 6.01.2018 tarihli görüşme). Irmak, özellikle kentin en önemli kolektif eğlencelerinden olan Hıdrellez Şenliğìne dair anlatılarda da hatırlanır. Nehirde taşımacılığın sürdüğü o günlerde (kabaca 1980 öncesi) sandallarla, motorlarla Boğaz'a -1rmağın denize kavuştuğu yere- yakın bir yerde olan Yirmibeş Kuyusu adlı yere gidilir, piknik yapılır, dans edilirdi. Hava karardıktan sonra fenerler yakılarak yine 1rmak yoluyla şarkılar söylenerek, kürekler çekilerek eve dönülür. Burada anlatılan, tam bir karnaval havasıdır. Karnavallar, farklı sinıflardan insanları bir araya getiren, toplumsal sınıflar arasındaki sınırların alt-üst edildiği etkinlikler olarak bilinir. Bartın'da bu bayramın diğer bayramlara göre neden daha büyük bir coşkuyla kutlandığ1 ve hemen herkesin anılarında önemle saklanmış olduğu sorulduğunda şu cevap alınmıştır: "Bu bayrama herkes, yani kentliler, köylüler, yaşlılar, gençler herkes katılırdı."

\footnotetext{
${ }^{3}$ Bartın'ın demiryolundan yoksun oluşu hem kentte yayımlanan yazılı kaynaklarda hem günlük sohbetlerde sürekli hakkinda konuşulan/ yazılan bir meseleydi. Yerel tarihçi Aşçı̆ı̆lu, demiryolunun Bartın'a gelmesinin "deniz ticareti yapan ve sözü geçen kimselerin" [çıkarları zedelenmesin diye] karşı çıktıklarından ve bu kişilerin nüfuzlarını kullanarak demiryolunun Bartın'a kadar ulaşmasının engellendiğinden şehirde yıllar y1lı hep söz edildiği bilgisini verir. Kaptanlarla görüşmelerimizde de konu dile getirilmiştir; isim verilmeden demiryolunun gelişiyle çıkarlarının zedeleneceğinden endişe eden büyük sermaye sahiplerinin Ankara'da önemli kişilerle görüşüp, nüfuzlarını kullanarak demiryolunu engelledikleri anlatıldı. Aşçıŏlu'nun (2011: 185) 2007 yılında bile bu konu hakkında yazmış olmasina bakılirsa bu olay, yerel toplumsal bellekte daha uzun süre silinmeden kalacaktır.
} 
(Görüşmeci XI, 16.01.2018). Hidrellez kutlamalarının önemi, Bartın'da ancak Kabotaj (Denizciler) Bayramı ile kıyaslanabilir. 1 Temmuz Kabotaj Bayramı'nın Bartın'da son derece önemsenerek kutlanmış olması, var oluşunu denizciliğe borçlu olan bir kent için şaşırtıcı olmasa gerektir. Denizciler Bayramı'na dair en çok anlatılan hatıranın, gençler arasında yapılan yarışmalar, özellikle "Yağlı Direk" adı verilen yarışma olduğu anlaşılmaktadır. Bu yarışmada yağlanmış ve ucunda bir bayrak olan direk bir gemiden veya karadan denize uzatılır. Yarışmacılar suya düşmeden direk üstünde yürüyerek bayrağa ulaşmaya çalışırlar. Bayrağı alan yarışmacı ödül kazanır. $\mathrm{Bu}$ tür buluşmaların özellikle dönemin koşulları içinde gençler açısından çok değerli olan sosyalleşme firsatları sunduğu da anlaşılmaktadır.

Bartın 1rmağı bunların yanında olumsuz hatıraların da başrolünde olabilmektedir. İki kolun birleşip kuzeye, Karadeniz'e doğru aktığı yerde bir zamanlar, yani ırmakta çocukların yüzebildiği yıllarda meydana gelen (çünkü burada anaforlar meydana geliyordu) boğulma vakaları, alt yapının yetersiz olduğu dönemlerde ırmağın oluşturduğu bataklıklardan kaynaklı sıtma vakaları (kentte Sitmayanı olarak bilinen mahalle yirminci yüzyılın ortalarına kadar bir bataklıktı) ve özellikle sel/ taşkın vakaları gibi... Tarihinde birçok sel vakası yaşayan Bartın'ın toplumsal hafizasında en derin izler bırakmış olan sel, günümüzde Büyük Sel adı verilen 1998 selidir. Birçok evin zarar gördüğü bu olay günümüzde de konuşulmakta, evlerde selden kalan çamur izlerinin hâlâ görülebildiği söylenmektedir. Ancak selle ilgili en önemli hatıralardan biri, kente hükümet tarafından yardım amacıyla gönderilen para hakkındadır. Bu konuda anlatılanları kısaca şöyle özetleyebiliriz: 1998 y1lında devlet selden zarar gören esnaf ve hanelere para yardımı yapacaktır. Ancak Bartın'ın nüfusuna oranla bankalarda en çok mevduat bulunduran il olduğu anlaşıldığından para yardımından vaz geçilir. Bu olay farklı değisskelerle anlatıldığından bir ortak hafizadan söz etmek zordur. "Para yardımı geldi, ancak kullandırılmadı, İl Özel İdare binasının yapımına harcandı" diyenler ve "Para geldi ama o dönemin siyasetçileri, bürokratları bir şekilde kendi çıkarları için kullandılar" diyenlerden başka çok az kişi de "Para yardımı yapıldı, zengin-fakir ayrımı yapılmadan birçok kişiye yardım yapıldığını biliyorum” demektedir.

\section{Kaptanlar ve Tüccarların Anlatılarında Bartın}

Bu bölümde doğrudan yaşayan kaptanlardan ve diğer kaynaklardan elde ettiğimiz bilgilerden hareketle gemi kaptanlarının/nakliyecilerin toplumsal-tarihsel konumunu olabildiğince belirginleştirmeyi amaçliyoruz.

Öncelikle çoğu kaptan kendi gemisinde kaptanlık yapiyordu. Gemilerin kardeşler arasında ortak olarak işletildiği de olurdu. Bunların yanında birçok gemisi olup kaptanları nakliyeden alınan belli bir pay karşılı̆̆ında çalıștıran zengin aileler de vardı. Kuşaklar boyu kaptanlık yapmış olan bir aileye mensup Görüşmeci IX, bu konuda şu bilgileri vermektedir: "Gemi alıp kendisi çalıştırmayıp başkasına, bir kaptana, iyi birisine teslim edip, dışarıdan adamları tamamlayıp çalıştıran da var. Yakın akrabalardan, tanıdıklardan. Mesela B... oğulları öyle yapt1... Ama genelde gemiye kaptanlar mutlaka az çok ortaktır. [Bir kişi] Aileden yoksa mülkü yoksa gemi yaptıramaz. Genelde varliklı aileler gemi yaptırır. Öyle kolay değil gemi yaptıramaz." (Görüşmeci IX, 23 Mart 2018 tarihli görüşme).

Batı Karadeniz'in hava koşullarının yarattığı bir ihtiyacı karşılamak üzere geliştirilmiş olduğu anlaşılan ve çektirme adı verilen ahşap gemilerde çalışış kaptanların bazıları ailelerinde kaptanlık mesleğinin yedi kuşaktır sürdügünü bildirmişlerdir. Evliya Çelebi'nin (2005) Seyahatname'si başta olmak üzere kent tarihine dair verilerin bulunabileceği kaynaklardan da Bartın'da denizciliğin geçmişinin XVI. yüzylla (ve muhtemelen daha eski tarihlere) kadar gidebileceği anlaşılmaktadır ${ }^{4}$. Günümüzde çektirme olarak sözü edilen gemiler motorlu gemilerdir. Kaptanlardan yalnızca biri çocukluğunda yelkenli gemileri gördügünü belirtmiştir (Görüşmeci VI, 23.04.2018 tarihli görüşme).

Kaptanların hepsi denizciliğe kendi sahibi/ortağ1 oldukları gemilerde ve çoğunlukla da kaptan olan babalarının veya akrabalarının yanında başlamışlardır. Kaptanlığa giden yolda usta-çırak ilişkisiyle öğrenilen mesleğin ilk basamağı makine dairesidir ve yapılan işin adı çarkçıllıtır. Kaptanlar, belli bir süre gemilerde çeşitli işleri yapan kişilerin, belli limanlara uğrayarak denizcileri sınavdan geçiren denizcilikle ilgili bakanlık yetkililerinin yaptıkları bir sınav1 geçenlere kaptanlık belgesi vermesiyle kaptan olmaktadırlar. Ancak bu belge yalnızca Cebelitarık Boğazı'na kadar olan limanlar arasındaki ulaşım ile sınırlanmaktaydı ve büyük çaplı taşımacılık yapılan gemilerde geçerli değildi (Görüşmeci I, 29.12.2017 tarihli görüşme).

Mektepli değil alaylı olarak yetişmiş kaptanlar, henüz telsiz ve benzeri gelişmiş araçların bulunmadığı ahşap gemilerinde, Batı Karadeniz'in zorlu havalariyla başa çıkmayı öğrenmek zorundaydılar. Eğitim süreci de mesleğe çarkçı olarak başlayan denizcinin yıllar içinde kaptanlığa yükselmesiyle son bulurdu. Gemilerde toplam personel beş kişiyi pek geçmiyordu ama üç kişiyle de yük taşındığı oluyordu. Gemilerde çok katı bir disiplin yoktu. Ancak kaptanlar son limana (malların teslim edildiği limana) denizcilerin parasını genellikle vermezlerdi. Çünkü çoğu çok genç yaşlardaki denizcilerin parayı

\footnotetext{
${ }^{4}$ Evliya Çelebi'den, Bartın fıçısının, Bartın küreğinin o dönemde ünlü olduğunu, yani yörenin ağaç işleriyle geçindiğini öğreniyoruz. Ayrıca Seyahatname' de Bartın'da kalyon üretildiğinden (Çelebi 2006: 352), Misır gemilerinin şehirden mal yüklediğinden (Çelebi, 2005: 85) söz edilmektedir.
} 
aldıktan sonra gemiden kaçıp eve dönmeleri (örneğin İstanbul'a varmadan, Zonguldak veya Ereğli limanında) nadir değildi. Bazı kaptanların para meselesinde daha katı bir disiplin uyguladığı, geçimlerini bu işten sağlayan denizcilerin parasını İstanbul, İzmir gibi şehirlerin eğlence mekânlarında harcamalarını önlemek amacıyla, Bartın limanında ödediği de olurdu.

Deniz kazaları kaptanlık mesleğiyle ilgili olarak ortak hafızada en çok iz bırakmış olaylardır. ${ }^{5}$ Aşağıdaki hikâye, bu izlere örnektir.

Babam anlatır: Kefken'den kalkmışlar hava bozuk. O geminin de makinası çok büyük değil. [Saatte] Beş mil gibi gidiyor gemi. Hafif bir rüzgâr var ama... Babam "kalkalım, gidelim" diyor ama dedem kabul etmiyor. Sonunda babamın 1srarı üzerine "tamam" diyor, kalk1yorlar. "Rüzgâr bir sertleşti, gitmiyor motor", diyor babam. İstanbul'a çok bir yol yok ama. Dedem kizıyor babama. "Dönelim" diyor, babam. Dedem "oğlum dönsek de kurtuluşumuz yok artık" diyor. Sonra bir şans işte, bir dönüyor hava, rüzgâr kıç taraftan geliyor, yelkenleri açıyorlar. O hava zaten beş altı saat kadar sürüyor. "Biz o arada İstanbul'a vardık," diyor babam. O akşam birkaç tane gemi batmış. (Görüşmeci IX, 23 Mart 2018 tarihli görüşme).

Bir başka çektirme kaptanı ise daha çok Batı'ya, İstanbul, İzmir gibi limanlara giden Bartınlı bir kaptanın deniz tecrübelerini şöyle ifade etmektedir:

Tehlikeli olanlar Kefken Adası, orada sular çok kabarır, deniz yapar. ${ }^{6}$ Bir de İstanbul Boğazı... Buralar çok deniz yapar, en tehlikeli yerler burasıdır. Gemide bir barometre var. Başka bir bok yok. Havay1 kendin kestireceksin, hava raporu falan yok... Zordu... Kuzey tarafi karardı. Dumanlar asıldı [bulutlar] bu, havanın geleceğine işarettir. Çıkmadan evvel... Bir limana indin. Limanda ancak geceyi göreceksin, yıldızlardan sonra çıkacaksın. Rüzgâr dışarıdan esmeye başlar... Açık, parlak hava poyraz havasıdır. Poyraz havası, Karadeniz'in en güzel havasıdır. Ama soğuk olur. Bizim en kötü havamız yıldız-yldız poyrazdır. Poyraz, giderken [İstanbul'a] uyar, gelirken uymaz. Dönüşte kafadan

\footnotetext{
${ }^{5}$ En çok anlatılan deniz kazalarından birincisi, 3 Mart 1963'te 7 mürettebatla batan Hacibaba Guleti'dir. $\mathrm{Bu}$ geminin Bartın'da yapılmış en büyük gemi olduğu bilgisi verilmektedir (Görüşmeci XIX, 30.12.2018 tarihli görüșme). Havanın durumuna bakarak yola çıkan gemi Şile açıklarında fırtınaya yakalanarak batmıştır. Unutulmayan bir diğer batma olayı da 18-19 Ocak 1931 Fırtınası'dır. Bu firtınada dev dalgalar kıyıları vurmuş, Zonguldak'ta ve Amasra'da limana yanaşan veya limanda bulunan gemileri sürüklemiş, batan ve karaya oturan gemiler olmuştur.

${ }^{6} \mathrm{Bu}$ araştırma sürecinde "deniz yapmak", "hava yapmak", "balık yapmak" gibi -Türkçe konusundaki hassas yazarların şimşeklerini çeken- ifadelerin en yașlı denizcilerin jargonunda da yani eskiden beri var olduğunu gördük.
}

geldiği için zor olur. Ama çok sağlam havadır, hiç korkmaya gerek yoktur. Bazı havalar birden değişir; o, tehlikeli havadır. [...] Şimdi Ereğli limanına indik, havayı beğenmedik. Artık geceyi bekleriz, havaya bakarız. Gece yldızları gördün, sahilden [karadan] esmeye başladığı zaman da kalkar gideriz. Zaten önünde de Ada var [Kefken adası] ondan sonra o hava İstanbul'a kadar elli yüz mil gider. Öbür gün akşama kadar sağlam hava devam eder. Hava kötüyse açıktan gideceksin, kıyıda deniz patlar. Açıkta olursa rüzgâra uyarız, manevra yapabilirsin. Rüzgârı kullanma imkânın var. Ama kıyıda hareket imkânın yok. [...] En tehlikeli yük, döküm yükü... Kerestenin falan tehlikesi yok (Görüşmeci I, 29 Aralık 2017 tarihli görüşme).

Buna karşın, yukarıdaki sözlerin sahibi kaptan, gemilerinden birini batırdığını ve can kaybı olmasa da mallarının halk tarafından, gözlerinin önünde yağmalandığını -acı bir tebessümle- anlatmıştır.

Geçmişte, deniz nakliyatçilığının kârlı olduğu dönemlerde, birçok kaptanın ve denizcinin battığ1 ve öldüğü anlatılmaktadır. Deniz kazaları, özellikle ölümlü kazaların daha çok İstanbul yolu üzerinde bir uğrak olan Kefken dolaylarında (Bartınlı kaptanlar buradan Ada olarak söz ederler) gerçekleştiği anlaşılmaktadır. Bir görüşmeci, bu durumu "Anam, neymiş bu Kefken! Çocukluğumda kimi sorsan "Babası nerede?" diye, boğulmuş, nerede Kefken'de” sözleriyle özetlemektedir (Görüşmeci XIII, 7 Şubat 2018 tarihli görüşme). Ancak dedesi ve babası da kaptan olan bir başka görüşmeci hiç kaza yapmadıklarını "Bizim ailede kaza olmaz" sözleriyle dile getirmekte ve şöyle demektedir: "Dedem iyi bir denizciydi, babam iyi bir denizci, iyi bir tüccard. Biz hiç kaza yapmadık" (Görüşmeci VI, 23.04.2018 tarihli görüşme).

Deniz kazaları genelde kış mevsiminde oluyordu. Normal şartlar altında kışın sefere çıkılmazdı. Ancak bazen hava aldatır ve özellikle günümüzdeki teknolojinin, hava raporlarının ve iletişim imkânlarının var olmadığı koşullarda, aldanan kaptanlar firtınaya yakalanır. Böyle bir günde firtınaya yakalanan gemileri anlatan denizcilerden biri șöyle demektedir: "Hava o kadar kötü ki, birbirine yakın gemiler bile batan geminin yardımına gidemiyor. 500 tonluk bir guletin batma vakasında, örneğin, başka bir gemi yardıma gitmeye korkuyor. Geminin başını çevirse, batmakta olan gemiye yanaşmak istese belki o da batacak. Neticede yardıma gidemiyorlar.” (Görüşmeci IX, 22 Mart 2018 tarihli görüşme).

Denizciler, firtınalı, dalgalı denizde gemi batıyorsa sağ kurtulmanın çok zor olduğuna inanıyorlardı. Öyle ki, kaptanların çoğunun yüzme bilmediğini öğrendiğimde duyduğum şaşkınlığ1 "Gemi batıyorsa yüzme bilsen ne olacak ki" diye cevapladı bir denizci. Sonra kötü 
havaların, dolayısıyla da deniz kazalarının ve batma vakalarının kışın olduğunu hatırlatıp şu örneği anlattı: "Bir keresinde yine İstanbul'a yük taşıyan bir gemi batıyor. Denizcilerden biri can yeleği sayesinde karaya çıkmayı başarıyor. Ancak soğuk havada iki üç saat içinde donarak ölüyor. Donmuş cesedini buldular sonra." (Görüşmeci IX, 22 Mart 2018 tarihli görüşme).

Kaptanlar yaptıklar1 "Biz denizin kamyoncusuyduk" sözüyle tanımlamaktadırlar. Gemiler çoğunlukla Bartın'da üretilen keresteyi başka kentlere, İzmir ve İstanbul'a taşımaktaydı. Keresteden başka en çok ihraç edilen bir başka ürün yumurtaydı. Yerel halkın ve denizcilerin "tabut" olarak adlandırdıkları uzun sandıklara istiflenen yumurtalar, köylerden tüccarlarca temin edilirdi. Görüşme yaptığım kaptanlardan biri, çocukluğunda limanda bekletilen bu yumurtalardan çaldıklarını gülerek anlatmıştı (Görüşmeci VII, 18 Ocak 2018 tarihli görüşme). İstanbul'dan veya İzmir'den dönüşte de boş dönülmez, genellikle tuz, gazyağ1 ve bakkaliye gibi ticari mallar Bartın'a taşınırdı. Bunun yanı sıra Zonguldak'tan kömür nakliyesi de yaygind. Sıradan bir nakliye işini denizcilerden biri şöyle özetlemiştir:

\begin{abstract}
Ben bir sene babamın emekli olduğu gemide 7980 arası çalışım. Benim ilk gemiye binişim altmış dört veya altmış beș (1964-65) ... Bizim gemimiz bir kereste fabrikastyla ortaktı. İzmir'e üç günde gittik İstanbul ve Çanakkale'de kâğıt (belge izin vs.) yaptırmanız gerekiyor. Bir iki saat gerekli ihtiyaçlarınızı gideriyorsunuz. Düzgün zamanlarda, havalar iyiyse. Kaptan devamlı gidilen yol olduğu için, hangi saatte gemisinin orada olacağını bildiği için ona göre çıkıyor. İstanbul'da boşa zaman geçirmiyor. İki saat içinde gümrükçüler gelir gemiye, sonra Çanakkale'ye gider. Orada da bir iki saat oyalanır. Sonra İzmir'e devam eder. Gemiyi yalnız bırakamazsın. Dışarı çıkıılırsa gemide biri iki kişi kalır. İzmir'de genellikle tuz alınırdı Çamaltı'ndan öyle gelinirdi. Sadece İzmir'e kereste çeken ve oradan tuz alan on-on beş gemi vardı burada [Bartın'da] (Görüşmeci IX, 22 Mart 2018 tarihli görüşme).
\end{abstract}

Kimi zaman, özellikle hava seyre uygun değilse veya taşınacak mal bekleniyorsa, günlerce limanda beklendiği de olurdu. Bu durumda denizde ve limanda zamanın nasıl geçirildiği sorusuna bir kaptan şöyle cevap vermiştir: "Bir kere bütün denizciler içer, 'İçmiyorum' diyen yalan söyler” (Görüşmeci VII, 18 Ocak 2018 tarihli görüşme). "İçmek"ten başka balık tutmak veya gemide bir nöbetçi birakmak şartıyla kente gitmek de başka seçeneklerdi. Varılacak limana ulaşıldığında denizciler sağ salim vardıklarını evlerine telgraf çekerek bildirirlerdi. Görüşmelerden, günümüzde gemilerde bulunan teknik araç ve imkânlardan yoksunluğun
Özellikle İkinci Dünya Savaşı yıllarında Karadeniz'de mayınların olduğu ve karartma uygulamasının sürdüğü zamanlarda işleri güçleştirdiği anlaşılmaktadır. Mayına çarparak batmak an meselesiydi. Buna rağmen o koşullarda da nakliyeciliği sürdüren kaptanlar vardı. Savaş yıllarında kaptanlar, alacakları yükün ağırllğını ve mayına çarpma ihtimallerini, alacakları yükün gemiyi mayınlara ne kadar yaklaştırabileceğini hesaplıyorlar ve buna göre karar veriyorlardı.

Kentte Kaptanlar, Kaptanoğlu, Hackkaptanlar gibi soyadları taşıyan birçok aile vardır. Görüştüğümüz birçok kişi ailelerinin kuşaklar boyu (bazıları beş-altı, bazıları en az yedi kuşak) denizci olduklarını söylemişler, Bartın'da dedelerinin kaptanlık mesleğini sürdüren birçok kişinin olduğu bilgisini vermişlerdir. Bu durumdan hareketle, denizciliğe ve kaptanlara dair yerel kültürel hafizada hatırı sayılır bir simgesel (deyim, hikâye, menkıbe, türkü vb) birikim bulmayı bekliyorduk. Ancak çok eski tarihlere uzanan ve temel geçim kaynağı olan yaygın bir uğraşın simgeleştirilmesine dair fakirlik bizi şaşırttı. Kentlilerin ortak hafizasında yer etmiş kaptanlıkla ilgili öyküler daha çok kazalarla, batma vakalarryla veya batmaktan kurtuluş ile ilgili hikâyelerdir.

Görüşmeler sırasında yaşlı bir kaptana bir Bartınlının "Bartınlı kadınlar eskiden 'Denizci koca hiç koca' derlermiş, çünkü denizciler günlerce, aylarca evde bulunmazmış" iddiasını aktararak, kadınların kaptanlarla evlenmekten kaçındığının doğru olup olmadığını sorduğumda, kısa ve net cevap verdi: "Evladim yalan bunlar, bunlara inanma. O zaman -parmak uçlarını birbirine sürtüp para işareti yaparakpara denizdeydi" (Görüşmeci VI, 23.04.2018 tarihli görüşme). Yine aynı görüşmede yaşlı kaptan kendi yaptığ 1 işi "Evladım biz, denizin kamyoncularıdık" cümlesiyle tanımlamıştır. Kaptanlar kendilerini tüccar/nakliyeci olarak tanımlasalar da mesleklerinin gerektirdiği bazı özellikler, örneğin işin bilgi, beceri ve emek gerektirmesi ve hayatlarını riske atmaları, onları daha çok para kazanma tutkusuna ve yabancılaşmaya karşı koruyan bir işlev görebiliyordu. Birçok kaptandan veya kaptanlıkla geçinen aileye mensup kişilerden "para kazanma hırsı"na karşı uyarıları dinledik: "Dedem hep şöyle dermiş 'denizde iki gemim, evde iki avradım, altın desen buradan eve yol olur. Bana kim ne yapabilir ki?’ Sonra gemileri batmış, işleri bozulmuş ve iflas etmiş. Kadınlar da onu terk etmiş. Babaannem 'Oğlum' derdi, 'benim babam sürünerek yaşadı ve öldü, biz de sürünerek yaşadık. Aman açgözlü olma, kibirli olma"' (Görüşmeci VIII, 12.02.2018 tarihli görüşme). Babas1 kaptanlık yapmış bir başka görüşmeci ise, "Gemi neden batar biliyor musun? Gemi dalgadan, havadan [firtına gibi etkenlerden] batmaz; gemi, hırstan batar" sözleriyle kâr hırsı sonucu aşırı yükle batan gemilere işaret etmekteydi. (Görüşmeci IX, 12. 01. 2018 tarihli görüşme). Ahşap 
gemilerde kaptanlık yapmış son üç kaptandan biri olan bir başka görüşmeciye ticaret dışında yasa dışı kaçakçılık gibi işler hakkında soru sorduğumda da yine para hırsına karş1 uyarılarla karşılaştım. Kaçakçıllı̆ın neden tehlikeli olduğunu önümüzdeki çayları örnek vererek anlattı: "Şimdi bu çayı şekersiz içiyorsun değil mi, eğer şekere alışırsan bir daha bırakamazsın. Kaçakçılıkta çok büyük paralar vardı. Ama bir kere alışırsan helal para az gelir, yapamazsın. Hem çok tehlikeli! (başparmağını ve işaret parmağını tabanca doğrultur gibi açıyor). Anladın mı?” (Görüşmeci VII, 18.01.2018 tarihli görüşme). Ayn1 görüşmede kaptan, bir yatta ayda bin lira karşıllı̆̆ında özel kaptanlık yaptığını ancak bu paranın çok az olduğunu; yalnızca bu işin kendisinde tutku olduğunu, bu yüzden sürdürdüğünü belirtmiştir. Bunun gibi örnekler çoğaltılabilir. Sonuç olarak para ve anlamın, ahlak ile kazanç hırsının sık sık karşı karşıya getirilişi kaptanların meslekleriyle ilgili anlatılarında tipiktir.

Yerel kaynaklarda Bartın'da görev yapmış bürokratlara, esnafa, Bartınlı ünlülere ve eski/köklü ailelere sayfalarca yer verilmesine karşın, kaptanlık ve kaptanlara dair çok az bilgi bulunabilmektedir. Aslında kaptanların basit nakliyeciler olarak görülmüş olması muhtemeldir. Kaptanların kahramanlaştırıldığ1 tek bir istisna, ticari başarıları nedeniyle Bartınlıların Kâruşağı lakabını verdiği (bu lakap soyadı kanunuyla soyadı olarak kullanılmıştır) bir kaptanın öyküsüdür. On dokuzuncu yüzyılda Mısır'ın İskenderiye kentinde de ticaret yaptığ 1 için gururla anlatılan bu Bartınlı denizci ailesinin hikâyesi şöyle anlatılmaktadır:

Memişustaoğulları lakaplı Ahmet Memiş Kaptan, kısa sürede kurmuş olduğu gemi filosuyla Osmanl1Rusya-Kırım arasında deniz ticaretiyle uğraşıyordu. Bir ticaret seferi sirasinda Karadeniz'in derin sularında şiddetli bir firtınaya yakalanan Memiş Kaptanın filosunda sağlam gemi kalmamış, gemilerin neredeyse tümü batmıss, elinde sadece arma denilen gemi araçları kalmıştı. Bu yüzden akıl sağlığı da bozulan Memiş Kaptan, etrafindaki insanların tepkisi ve alayları yüzünden bir süre evinden hiç çıkmamıştı. Ailesinin ekonomik durumu da kötüleşen Ahmet Memiş'in hanımı evlere temizliğe ve çamaşır yıkamaya gitmeye başlamıştı. O günlerde Bartın'ın yeni zenginleri bir araya gelip gemiler yaptırmışt1. İstanbul'a barut fıçısı, fiçı tahtası ve onun gibi bazı eşyalar satmaya gideceklerdi. Ama bir sorun onlar1 bekliyordu. Gemiler hazır olmasına hazırdı, fakat gemileri çalıştıracak armalara ve armaları satın alabilecek paraya sahip değildiler. Düşünüp taşınıp Memiş Kaptan'a gitmeye ve onda bulunan armalar1 istemeye karar verdiler. Armaların karşıllı̆ı olarak, kazanılacak meblağdan pay önerdiler, Memiş Kaptan da bunu kabul etti. Denizin ona iyi geleceğini düşünen hanımının 1srarları sonucunda, Bartınlı zenginler
Memiş Kaptan'1 da İstanbul'a götürmeye karar verdiler. Deniz, Memiş Kaptan'ı hiç değiştirmişe benzemiyordu. Yola çıkalı birkaç gün olmasına rağmen kamarasından hiç çıkmamışı. Ta ki o ana kadar. Filo çok şiddetli bir firtınaya yakalanmıştı. Bartınlı zenginler ne yapacaklarını bilmiyorlardı. Akıllarına, pek de aklı yerinde olmayan Memiss Kaptan gelmişti. Böylece yola çılkıldığından beri ilk kez kamarasından dışarı çıkıyordu. Zengin tüccarlar ona durumu anlatmaya çalıştılar uzun süre. Sallanan gemi güvertesinde bir süre boş boş baktı onlara Memiş Kaptan. Sonra bir anda tayfalara emirler yağdırmaya başladı. Memiş Kaptan'ın emirleri filoyu amansız firtınada batmaktan kurtarmıştı. Hem sağ kaldıklarına hem de mallarına bir şey olmadığına çok sevinen zengin tüccarlar malların bir bölümünü Memiş Kaptan’a verdiler. Tüccarların hepsi, İstanbul'a varır varmaz ellerindeki malları satarak iyi paralar kazandılar. O zamanki piyasaya bakan Memiş Kaptan bekledi ve ona verilen malları Balkanlarda çıkan isyan zamanında satarak büyük paralar kazandi. Eskisinden daha da zengin olan Memiş Kaptan, Bartın'da büyük ün yaptı ve onu gören herkes karlı iş yaptı diye diye lakabı "Kâr uşağı"na çıktı. Soyadı kanunu ile de Kâruşağızade soyadını aldılar. [...] (Taner Tözün, 31.01.2011 http://www.tanertozun.com/yazi/guncel/195karusagi-konagi-hakkinda-yok-olan-hikâyeler.html (erişim: 11/02/2018)

Yerel yazarların çalışmalarında adlarına rastladığımız az sayıdaki kaptandan biri de Hacali Kaptan'dır. Hakkında şu bilgiler verilmektedir:

Hacali Kaptan 26 yaşında iken Hacca giderek "Hac1 Halil" mahlası ile anılmaya başladı. İyi bir gemici olan Hacali yüzmeyi bilmiyordu. 75 yaşına kadar gemicilik yaptı. Yedi çocuk sahibi olan Hacali Kaptan 7. çocuğu erkek olunca sevincinden BartınZonguldak seferini bir defa bedava taşımıştır. Aşağıda örnekte görüldüğü gibi Hacali’nin motoru yörede manilere bile konu olmuştur. Hacali Kaptan 1970 yıllnnda 87 yaşında vefat etti. (Çilsüleymanoğlu, 1996: 402).

Yukarıdaki Kâruşaklar'nın mağaza açarak tarihe geçtikleri -ve günümüzde Bartınlıların da gururla anlattıkları öykülere konu olmuş- İskenderiye Bartınlı kaptanların gittikleri muhtemelen en uzak limand. Daha çok İstanbul ve İzmir'e ve Karadeniz'deki limanlara yük taşınmaktaydı. Kırım görüşmelerimizde adı en çok geçen limandır. Kırım limanının geri plana düşmesinde, belki savaştan da önemli bir etken Birinci Dünya Savaşı sırasında 1917'de Ekim Devrimi ile eski Rusya'da sosyalist rejimin kurulmasıydı. Bu dönemdeki değişimin Bartınlı tüccarları nasıl etkilediği şöyle anlatılır: "Devrim olunca eski Rus rubleleri geçersiz 
olmuş. Bu paralar neredeyse bir kâğıt (A4 boyutunda) kadarmış. Ellerinde bu rublelerden kalan, Rusya'dan alacağı olan birçok tüccar iflas etmiş. Bu kâğıt paraları atmamışlar, kadınlar mutfaklarda kaplarının altına örtü olarak sermiş!” (Görüşmeci IV, 4 Mart 2018 ve çeşitli tarihlerde görüşmeler). Bu hikâyede, dünyanın ve bölgenin tarihini değiștirmiș bir büyük olayın yerel hafizada yine kent ekonomisinin merkezinde yer alan deniz ticareti bağlamında hatırlandığını görmekteyiz. Para, kâr, kazanç, ticaret, iflas sözcüklerinin s1k s1k kullanıldığı hikâyeler, bir liman kasabasında egemen burjuva kültürünün yansıması olarak yorumlanabilir.

Buradan hareketle kaptanların yerel tarihte ve anlamlı olan etrafinda bir araya getirilmeye çalışılan kentsel hafizalarda neden çok önemli bir yer tutmadığına dair fikir yürütebiliriz. Her şeyden önce kaptanların kendileri de yaptıkları işin rutin nakliye işi olduğunu vurgulamakta ve birer tüccar olduklarını söylemektedirler. Üstelik para kazanma çabasının anlatmaya değer oluşu bir yana, bu faaliyete karşı anlam ve değerler dünyasını korumak gibi sürekli sorumluluk duygusuna sahip oldukları ve bu yönde çaba sarf ettiklerini dile getirmişlerdir. Toplumsal hafıza ve anlam dayanakları açısından kaptanların ve kaptanlığın konumu, Kagarlitsky'nin (2012), geç kapitalizmin krizini, piyasa-kültür ilişkisi bağlamında analiz ettiği bir makalesindeki yorumları hatırlatmaktadır. Kapitalizmin tarihi boyunca piyasayı dengeleme işlevi gören ve görece özerk bir yapısı bulunan, burjuvazinin de bu özerkliğini desteklediği kültürel alanın (sanat, bilim, inançlar vb. anlam üretim alanları) "artık piyasanın büyümesini düzenleyecek, yönlendirecek ya da ona yakıt sağlayacak bir mekanizmadan [yoksun] olduğunu" belirtmektedir. Kagarlitsky'ye göre "piyasanın ideolojik dürtülerinin sanat alanında işe yaramadığı daha on dokuzuncu yüzyılda açılılı kazanmıştır. Satıcı estetik bir varlık değildir. Onu kahramanlaştırmak imkânsızdır. Kendine has bir güzel ideali yoktur onun. JacquesLouis David ve diğer Fransız Devrimi sanatçılarının burjuvazinin gündelik hayatından değil, Antik Roma kahramanlarının yiğitliklerinden esin almasının nedeni de budur." (Kagartiltsky, 2012: 164)

\section{Toplumsal hafızada gemi inşası ve gemi mimarları}

Gemi üretimi, özellikle yöredeki ustaların Karadeniz'in zorlu koşullarına uygun olarak geliştirmiş olduğu söylenen çektirme adıyla bilinen gemiler, günümüzde kentin simgelerinden biri olarak görülmektedir. Kent Müzesi'nde ve kamusal mekânları süsleyen kent tarihinden sahneler içeren fotoğraflarda bu gemileri görmekteyiz. Bartınlı mimarlardan devraldığı geleneksel gemi yapım bilgi ve teknikleriyle modern mühendislik bilgilerini birleştirerek günümüzde Bartın, Kurucaşile'de inşa ettiği yatlarını başka ülkelere ihraç eden mühendis Hüseyin Çoban (2009), 12. Uluslararası Tekne ve Gemi
Arkeolojisi Sempozyumu'nda sunduğu bir bildiride şöyle demektedir:

Öteden beri Batı Karadeniz kıyı kültürleri zorlu deniz koşulları tarafindan biçimlendirilmiştir. Karadeniz coğrafyası sahil yerleşimlerinde hayatı daha da zorlaştırır. Teknelerin sı̆̆ınabileceği fiyortların ve koyların seyrekliği oldukça belirleyici bir fark yaratır. Tekne tipleri ve onların inşa teknikleri kötü hava koşullarında hemen bir sığınak bulmanın güç oluşu etkeni tarafindan belirlenmiștir. Teknelerin bir koya, bir fiyorda hatta bir dalgakıranı olan bir limana bile sığınma şansindan yoksun oluşu nedeniyle gemilerde kullanılan ağaçlar daha dayanıklı olmalı ve daha sağlam şekilde birbirine bağlanmalıydı. Güçlü dalgalara karşı bu gemiler, daha dirençli olmalı ve hızla karaya çekilebilmeliydi. [...] Ve bölgenin Ahşap Tekne Zanaatkârları bütün bu koşulları dikkate alan bu gemileri, tekne tiplerini yarattılar (Çoban 2009: 4).

Buradaki kadar akademik bir üslupla olmasa bile yerel halktan görüştüğümüz hemen herkes gemi üreticilerini övme eğilimindeydi. Gemilerin Bartın tarihi açısından önemli oluşuna paralel olarak gemi mimarlarının da kentin geçmişine dair anlatıların kahramanları olduğu söylenebilir.

Daha önce kaptanların çoğunun aynı zamanda gemilerin sahipleri olduğu söylenmişti. Kaptanların ve denizcilerin anlatılarında gemilerden isimleriyle söz edilir ve geminin nasıl yapıldığı, ne zaman elden çıkarıldığ veya nasıl kaybedildiği, özetle hayat hikâyesi ayrıntılarıyla anlatılır. Yaşlı bir kaptan, babası ve amcasıyla birlikte ortak nakliyecilik yaptıkları ilk gemisinden söz ederken "Her ağacinın omzumda izi var" ifadesini kullandı. $\mathrm{Bu}$ tür ifadelerdeki anlam yoğunluğu, gemilerin birer "ekmek teknesi" olmanın da ötesinde, onu üreten ve bu üretimde emeği olanlardan parçalar taşıyan anlamli veya kişilik sahibi nesneler olarak görüldüğünü anlatmaktadır. $\mathrm{Bu}$ görüsslerimizi paylaştığımız ve gemi üretiminde uzman bir görüşmeci de yorumumuzu destekleyen başka örnekler anlattı. Örneğin bir kaptan artık ömrünü tamamlamış gemisini isteyenler olmasına rağmen satmaya kıyamamış, kendisi parçalamıştı. (Görüşmeci XIX, 30.12.2018 ve çeşitli tarihlerde görüşmeler).

Aslında gemiler, sahipleri tarafindan kişiselleştirilmesi, birer sanat eseri olarak gemi mimarlarının bilgi ve ustalığını temsil edişi, yalnızca kaptanlar/tüccarlar için değil yüzlerce aile için geçim kaynağ1 olmas1 gibi nedenlerle (gemilerin omurgalar1 için şart olan eğri ağaçlar ormanlardan kaçak olarak temin eden "eğriciler", ağaç gemi makarası imal eden makaracılar, pamuk ve zift kullanarak kalafatlama işlemi yapan kalafatçılar, gemi halatları ören halatçlar ve kalay çivi üreten kalaycılar, tersanelerde çalışanlar vd.), ilk 
yapılmaya başlanmasından ömrünü tamamlamasına kadar birçok ritüele konu olmaktaydı. Kentin en yaşlı kaptanının yanında çıraklıkla başlayan meslek hayatını günümüzün modern gemilerinde sürdüren bir kaptanın verdiği aşağıdaki bilgiler, gemi yapımı örneğinde ortak anlam üretimi ile üretimdeki ortaklık arasındaki ilişkiyi anlamaya yardımcı olabilir:

Gemi inşasında kaç işçi çalışıyor, bak: Baltacı ayrı... Baltacı [geminin gerekli parçalarını] çırpıdan [ağacın ham halinden] yontardi. Burgucu, tahtayı delecek, şimdiki gibi çivi de yok. Çivi yok o zaman. Kalaycilar dövme [el yapımı] çivi yaparlardı. Keserci... Delikçi ayrı... Hızarcı ayrı. Kocaman bıçkıyı çıkarırlardı ağaca, biri aşağıda biri yukarıda haşır haşır haşır... keserlerdi ağac1. Her şeyi kendin yapacaksın. Ayak keserci... Ayakkeseri diye bir şey var, kazma gibi bir şey ama kocaman ağzı vardı o keserin, jilet gibi... Çok ayaklar gitti o zamanlar. ... Gemi mimarı endazeyi kurar, bu hesap işi, denge işi. Hüseyin Kaynarca, en iyi mimar oydu... Gemi mimarları, o çarıklı mimarlar, eğitimli, matematik bilen adamlar değildi. Mesela geminin bodoslamasını dikeceği zaman adam... Mesela duvarcı ustası bile şakul kullanır değil mi?... $\mathrm{Ha}$, [gemi mimarr] keseri şöyle alır eline tutar [elinde keseri tutup gözüyle ölçüyormuş gibi yapıyor] "Şu yana gel, bu yana gel hoop! Hoop! Çak!’ İşte böyle yaparlardı... Ama eline bir ip al, şöyle geminin bir o tarafını bir bu tarafını ölç, milim oynamaz! [ölçü aletleri ve bilgileri olmamasına rağmen mimarların gemilerde gerekli simetriyi ve dengeyi sağladikların ifade ediyor] El terazi, göz nizami [bu sözün bu işlerin nasıl yapıldığını anlatmakta kullanılan bir kalıp söz olduğu anlaşılmaktadır] ... Geminin altı kaplanacak. Kayın ağacı kullanılır. Su kesimine kadar [su hizasının alt kısmı]. Geminin altı, tavası kayın ağacıdır. Dışarısı, üst taraflar meşe. Çünkü sert ağaç, damarlı ağaç, dayanıklı... En üstü, çam; güverte, çam. Alt omurga kayın, suda çürümez kayın, en çok o dayanır. Bodaslama, meşeden olur. Eğriler, döşekler, istralyalar, meşe... Yukarısı meşe. Kayın ağacinın özgül ağırlığıynan, çam ağacinın özgül ağırlı̆̆ değişir... En ağırı kayın, sonra meşe, sonra kestane, sonra çam [bu siraya göre ağaçların ağırllğı geminin alt tarafindan üste doğru azalmaktayd1] (Görüşmeci X, erkek, 65, 22.01. 2018 tarihli görüşme).

Gemilere dair ritüellerin en önemlisi gemilerin suya indirildiği (yerel deyişle 'gemi atma') törenleriydi. Gemi suya indirileceği zaman, halka duyuru yapıllır, neredeyse bütün kasabanın orada hazır bulunması istenirdi. Çocuklar ve kadınlar dahil olmak üzere halk onlarca manda tarafindan çekilen geminin suya indirilişini izler, lokumlar, şekerler dağttılır, gemi dualarla suya indirilirdi. Müftünün öncülüğünde yeni gemi için herkesin dua etmesi, gemileri katılımcıların nazarında daha da önemli/uhrevi kılmış olmalı. Dua herhangi bir ticarethanenin açlişında söylenebilecek temennilerle (bol helal kazançla dönsün vb.) başlar, "Başı kayaya kıçı karaya gelmesin", "Sonu hamamda yakılmak olsun!" gibi temennileri dile getiren standartlaşmış bir duaydı. $\mathrm{Bu}$, gemilerin ömrünü denizde bir kaza sonucu batarak değil doğal ömrünü tamamlayıp oduna dönüştürülerek tamamlanmasının arzu edildiğini ifade etmekteydi. Böylece gemi atma ritüelleri, kent için son derece önemli bir üretim etkinliğini (yalın gerçekliği) dini öğeler de içeren kolektif eğlenceye, duygu paylaşımını sağlayan etkinliğe dönüştürerek, ticari bir insan faaliyetini anlam ve değerlerle donatma işlevi görmekteydi.

Gemi inşası ve gemi mimarlığ1 nasıl ki Bartın kimliğinin ve toplumsal hafizasının merkezinde yer alıyorsa, geminin suya indirilme töreni de bu merkezin çekirdeğini oluşturur. Bartın'n tarihine dair kitaplarda yer alan veya internette bulunabilecek birçok fotoğrafta, özellikle geminin karadan suya indiği anın dondurulduğu görülür. Gemi atma törenlerinin neden bu kadar ilgi çektiği veya izleyenlerin bu törenlerde izlemeye değer ne buldukları sorusuna verilen cevaplardan biri şudur: "O zaman küçük bir kasabada, televizyonun, sinemanın olmadığ 1 bir zamanda en büyük eğlence oydu. Tahta g1cırtıları, mandaların böğürtüleri, 'Yah de! Yah de!' bağırışları... Kalabalığın gürültüsü... hepsi birbirine karışır... Gemileri çekmekte zorlanan mandaların bazen nallar1 çıkıp havaya firlar... Bir şenlik, bir kıyamet..." (Görüşmeci X, 65, erkek, 22. 01. 2018 tarihli görüşme). Bir başka görüşmeci ise şunları söylemektedir: "Belediyeden anons edilirdi. Filanca gün filancanın gemisi suya indirilecek. Bütün şehir, kadın, çocuk kim varsa orada olurdu. Lokum dağitılırdı. Tabii o zamanlar başka eğlence yok; sinema yok, televizyon yok. En büyük eğlence gemilerin suya atıldığ1 törenlerdi." (Görüşmeci XII, 67, 3.3.2018 tarihli görüşme). Genç kızken bu törenleri izlemeye giden (Görüşmeci XI 86, 7.02.2018 tarihli görüşme) "Geminin suya indirildiği ana tanık olursak bizim de hayatta güzel şeyler yaşayacağımıza, bahtımızın açık olacağına falan inanırdık." sözleriyle söz konusu olaya verilen anlamlar konusunda fikir vermektedir. Öte yandan hamile kadınlar özellikle geminin suya indirildiği ana tanık olsunlar diye $1 \mathrm{rmak}$ kenarına getirilirdi. Çünkü geminin suya indirilişini görmenin doğumu kolaylaştıracağı gibi bir inanış vard1. ${ }^{7}$

\footnotetext{
Adanır (2018: 102) İslamiyet'i kabul etmelerinden önce Türk toplulukları arasında yaygın inançlarda su kültünün yerine işaret ederek günümüz Türkiye'sine kadar ulaştı̆̆ını gösteren örnekler verir. "Bu yüzden Fırat'ın kaynağının gökte olduğu düşünülür. Çevre halk1 bu suyun kaynağında olağanüstü güçler olduğuna inanır. Güç doğuran kadınlara bu sudan içirilir. Çeşitli hastalıkları olanlar iyileşmek için kaynağın çevresinde yedi kere dolanırlar ve üzerlerine sudan serperler. Denizlerin de kurban isteyen varlıklar olduğu ve gazaplarını kurban vererek dindirmenin mümkün olduğu gibi inanışlara halen rastlanmaktadır. Örneğin Zonguldak'ta anlatılanlara göre, Karadeniz'e açılan balıkçıların kadınları, fırtına
} 
Kaptanlar ve denizciler kendi hikâyelerinden çabucak sıkılıp gemilerin inşasına geçerler, gemi mimarlarının isimlerini (günümüzde bunlardan hiçbiri hayatta değildir) bir çırpıda sayarlar. Bu gemi mimarları herhangi bir eğitim almamıştır. Ancak el-göz yordamıyla iş görürler, işlerini usta-çırak ilişkisi temelindeki eğitimle öğrenmişlerdir. Herkesten sayg1 görmelerini sağlayan, bilgi ve becerilerinin yanı sıra, yine yaptıkları işin niteliği ile ilgili olarak ilkeli ve disiplinli olmalarıydı. Kaptanların aynı zamanda tüccar olduğu ve "aşırı kâr hırsının" deniz kazalarının başlıca nedenlerinden olduğu (öyle olduğunun düşünüldüğü) koşullarda, bu hırsı dizginleme rolünün bir kısmı onların üzerine düşüyordu. Gemiyi teslim ederken, tüccarlara mutlaka "Her şey para değil, hırslı olma!" gibi öğütler verirlerdi. Kimi gemi sahiplerinin -ki, genellikle kaptanlardır bunlar- gemileri tersanede inşa halindeyken, geceleri gizlice gemilerinin -daha fazla yük alsınlar diye- gövdesini genişletmek için müdahale ettikleri, bu durumu sabah işe başlayan gemi mimarlarının fark ederek gemi sahiplerini azarladığ1 anlatılmaktadır. (Görüşmeci XIX, 16.02.2019 tarihli görüşme).

\section{Sonuç}

Bu çalışmada küçük bir kasabanın bir ticaret ve sanayi kentine dönüşmesinin yaklaşık iki aşıra yayılan tarihinden belleklere hangi izlerin kaldığını, kent geçmişinin günümüzde temsil edildiği haliyle toplumsal hafizaya, yerel simgesel ifade biçimlerine nasıl yansıtıldı̆̆ını ve kentin öz imgesinin oluşturulmasında tarihsel öğelerin nasıl kullanıldığını araştırdık. Bunun için aralarında eski ahşap gemilerde/çektirmelerde kaptanlık yapmış son üç kişinin de olduğu görüşmelerden elde edilen verileri kullandık. Kimlik inşasında ortak bir geçmiş varsayımı ve düşüncesi temel önemdedir ve bu geçmişin ortak duygular yaratması da beklenir. Toplumlar ortak geçmişten değerli ve anlamlı gördükleri öğeleri seçip geçmişi yeniden kurgularlar ve önemli öğeler bugünkü birliği/dayanışmayı temsil etmek üzere simgeleştirilir. Bartın'da hafızaların, Bartın Çayı'ndaki şenliklerin,

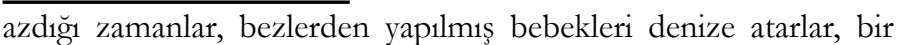
ineğin sütünü sağıp denize dökerlermiş. Boratav, gemicilerin, suyun yüzeyine zeytinyağı dökerek azgın dalgaları yatıştırabileceklerine inanmalarının da bir bakıma ona hükmeden, cisimlendiren varlığa sunulan bağıș simgesi olarak değerlendirilebileceğini söylemektedir (Adanır, 2018: 102-3). Burada inançların tarihsel sürekliliğinden çok doğayla benzer şekilde kurulan ilişkilerin simgesel etkinlikleri de benzeştirdiğinden söz edebiliriz. Ayrıca ritüeller gibi büyü benzeri pratiklerin de toplum için önemli olanm altınm kalin çizgilerle çizilmesi mecazıyla ifade edilebilecek bir kültürel/kolektif eylem olduğunu söyleyebiliriz. Bu noktada gemi atma ritüelinin de toplumun geçimi için en önemli varlıkların, kişilerin ve nesnelerin hatırlatılmasına süreklilik kazandıran iletişimsel eylemler/anlam aktarımları olduğu söylenebilir. Bir başka deyişle, bu tür törenler, maddi olana manevi bir k1lıfın giydirildiği, maddi olanla manevi olanın bütünleştirildiği kolektif pratiklerdi... Geminin doğumu (hayatına başlaması) ile çocuğun dünyaya gelişi arasında ve su ile hayat arasındaki mecazi bağ ise fazla yorum gerektirmeyecek denli açıtır. ırmağa gemi indirme törenlerinin ve gemi mimarlarının merkezinde olduğu bir öyküde kolektif hale geldiğil ortak anlamlarda buluştuğu söylenebilir. Bu merkezden uzaklaştıkça hatırlanan ve önemsenenler sınıfsal konumlara, yaşa, statüye göre çeşitlenir ve giderek daha çelişkili bir hâl alır.

Kentin önemli kamusal mekânlarını süsleyen ve geçmişi yansıtan fotoğraflar arasında gemi fotoğrafları, özellikle gemilerin suya indirilme anları öne çıkmaktadır. Kentin tarihi ile bu eski ailelerin (yani asıl Bartınlıların) tarihini özdeşleştirme eğilimi, kentte toplumsal hafıza oluşturma işlevi gören cadde ve sokaklara verilen isimlere de yansımaktadır. Bu isimler arasında eşraf ve âyandan ailelerine mensup kişilerin, Sanayi ve Ticaret Odası gibi örgütlerin kurucuları, fabrika sahipleri vb. kişilerin isimleri dikkat çekmektedir. Bu isimler arasında kaptanlığa, denizciliğe gönderme yapan veya doğrudan bir kaptanın adını taşıyan herhangi bir örnek yoktur. Köylüler ve işçileri hatırlatacak (müzedeki bir-iki resim vb. dışında) temsillere pek yer verilmez.

Yazılı kaynaklarda adlarına çokça rastlanan üst düzey memur ve siyasetçilerin, önemli ailelere mensup olup vekil, belediye başkanı veya belediye meclis üyesi seçilmiş kişilerin sözlü görüşmelerde pek hatırlanmadığını (Kemal Samancioğlu ve belki birkaç kişi dışında) veya olumsuz eylem ve özellikleriyle hatırlandığını gördük. Kolektif bellekte derin iz bırakmış olaylarda (1998 seli, demiryolunun Bartın'a uğramaması gibi) üst sınıfların kendi ç1karlarını kentin çıkarlarının önünde tutan figürler olarak hatırlandığı görülmektedir. 1980 sonras1 dönemde özellikle çevre sorunları bağlamında, fabrika sahipleri ve yerel devlet yetkilileri ile Bartınlılar arasında çatışmaların arttığ da yine yerel kaynaklardan (basın arşivinden ve sözlü aktarımlardan) anlaşılmaktadır.

Bartınlı yazarlarca yayımlanan kitaplarda ağırlık eşraf ve âyanda, tüccarlar, siyasetçiler ve bürokratlardadır; kaptanlara ve gemi mimarlarına pek az yer verilmektedir. Buna karşın alanda yaptığımız görüşmelerde anlatıların, yani sözlü hafızanın merkezinde gemi mimarlarının ve gemi üretiminin olduğunu gördük. Hiçbir gemi mimarı hayatta olmadığı için gemi yapımı ile ilgili bilgileri kaptanlar ve vaktiyle kaptanlara çıraklık etmiş, gemilerinde çalışmış denizcilerden (bazıları günümüz modern gemilerinde kaptandır) aldık. Başka görüşmecilerin anlatılarında olduğu gibi kaptanların anlatılarında da vurgu, ağırlıklı olarak gemi inşa süreci ve gemi mimarlar1 üzerindedir. Gemi mimarları hakkında hiçbir olumsuz ifadeye rastlamadık ve görüşmelerde duymadık. Bu zanaatçılar, emekleriyle geçinen, bilgi ve ustalıkları sayesinde para kazanan kişilerdi. İç bölgelerin ihtiyacının karşılanmasında kritik öneme sahip bir liman kentinin ekonomisi açısından son derece stratejik olan nehir-deniz taşımacıllı̆̆ının güvenle sürdürülmesi ustaların bilgive becerisine, tecrübelerine, yanı sıra onların 
iş etiğine bağlıydı. Bunun yanında ürettikleri gemiler, değerli nesnelerdi ve sanat eserleri olarak görülebilirdi. Bu gemiler, ustaların bilgi ve becerilerinin izlerini, onların imzalarını taşıyan eserler olmanın yanında kullanan kaptanların, gemi sahiplerinin kaderlerini bağladıkları, ailenin geçiminde oynadıkları roller nedeniyle de oldukça değerli görülen nesnelerdi. Bu nedenlerle gemiler, kent halkının en çok rağbet ettiği, bir araya geldiği ritüellerin konusu oldular. Aynı nedenle günümüzde çektirmelerin küçük-büyük modellerine kentin birçok yerinde simge nesneler olarak yer verilmektedir. Özetle paranın, kârın, kazancın, ticari faaliyetin toplumun çoğunluğunun uğraşı olduğu bir yerde, anlamlı ve değerli olanı devşirmek üzere geçmişe yönelenler, gemi üretimini ve yaptıkları iş -bu işin toplumsal önemi nedeniyle- salt kişisel çıkarı arttırma çabasına indirgenemeyen gemi mimarlarını hatırlamaktadırlar.

\section{Kaynakça}

Adanır, O. (2018). Orta Asya-Anadolu Ekseninde Batıl İnanç ve Âdetler, Doğu Batı, 84, 97-108.

Assman, Jan. (2018). Kültürel Bellek, 3. Basım (A. Tekin, Çev.). İstanbul: Ayrıntı Yayınları

Aşçıŏglu, E. (2011). Bartın'da Tarih. Bartın: Sargın Ofset Matbaacılık.

Aydın, S: (2003). Kimlik, S. Aydın ve K. Emiroğlu (Ed.) içinde, Antropoloji Sözlüğ̈̈. (s. 469-477). Ankara: Bilim ve Sanat Yayınlar1.

Bauman, Z. (2005). Bireyselleşme. (Y. Alogan, Çev.). İstanbul: AyrintıYayınları.

Bauman, Z. (2017). Kimlik. (M. Hızır, Çev.). Ankara: Heretik Yayınları.

Caunce, S. (2001). Sö̊lü Tarih ve Yerel Tarihçi. (B. B. Can ve A. Yalçınkaya, Çev.). İstanbul: Tarih Vakfı Yurt Yayınları.

Çalak, I. E. (2012). Kentsel ve Kolektif Belleğin Sürekliliği Bağlaminda Kamusal Mekânlar: ULAP Platz Örneği, Almanya, Tasarm Kuram, 13, 34-47.

Çilsüleymanoğlu, S. (1996). Bartın Halk. Kültürü, 2. Cilt. Ankara: Türk Tarih Kurumu.

Çoban, H. (2009). Inebolu Boat - the Last "Shell First" Construction Survived in the Black Sea and the Evolution of Boat Building in the Black Sea Coast of Anatolia, 12. Uluslararası Gemi ve Tekne Arkeolojisi Sempozyumu, 12-18 Ekim 2009 İstanbul ve Amasra, 104-107.

Danacıoğlu, E. (2007). Geçmişin İzleri Yamıbasımızdaki Tarib İcin Bir Kılavuz: İstanbul: Tarih Vakfi Yurt Yayınları.

Ekinci, İ. (2013). Karadenizde Âyanlar ve Denizcilik, Karadeniz. Arastırmalar, 37, 15-49.

Emiroğlu, K. (1985). Uruk'tan Ankara'ya II, Tarih ve Toplum, 17, $40-46$

Ergenç, Ö. (2012). Şehir, Toplum, Devlet Osmanlı Tarihi Yazıları. İstanbul: Tarih Vakfi Yurt Yayınları.

Çelebi, E. (2005). Seyahatname, 2. Cilt, 1. Kitap, Y. Dağlı ve S. A. Kahraman (haz.), İstanbul: Yap1 Kredi Yayınları.
Çelebi, E. (2006). Seyahatname, 3. Cilt, 1. Kitap, Y. Dağlı ve S. A. Kahraman (haz.), İstanbul: Yap1 Kredi Yayınları.

Halbwachs, M. (2017). Kolektif Hafı̨a. (B. Barış, Çev.). Ankara: Heretik yayınları.

İlyasoğlu, A. (2006). Yakın Dönemde Tarihe İlginin Farklılaşması Sürecinde Sözlü

Tarih Alanının Türkiye'deki Gelişimine Bir Bakış, A. İlyasoğlu ve G. Kayacan (ed.) içinde, Kuşaklar Deneyimler Tanıkhklar Türkiye'de Sözlü Tarih Calısmalar Konferansı 26-27 Eylül 2003, İstanbul (s. 15-22). İstanbul: Tarih Vakf1 Yurt Yayınları

İnce, G. B. (2010). Medya ve Toplumsal Hafiza, Kültür ve İletişim, 13(1), 9-29.

Kagarlitsky, B. (2012). Piyasa, devlet ve klasik kültürün krizi, J. D. Backstein vd. (ed.) içinde, Farkh Dünyalar Düsünmek. Felsefe, Siyaset ve Sanat İcin Moskova Konferansı (ss. 163-169). İstanbul: Metis Yayınları.

Meeker, M. E. (2005). İmparatorluktan Gelen Bir Ulus - Türk Modernitesi ve Doğu Karadeniz'de Osmanl Mirası. İstanbul: İstanbul Bilgi Üniversitesi Yayınları.

Metin, C. (2017). Sözlü Tarih ve Türkiye'deki Gelişimi. http:// www.ait.hacettepe.edu.tr/akademik/arsiv/soz.htm (Son Erişim: 25.03.2019)

Nora, P. (2006). Hafıza Mekânları. (M. E. Özcan, Çev.). Ankara: Dost Yayınları.

Özbudun, S. (2014). Bir "Praksis Antropolojisi” İçin, İnsancıl, 285, $2-10$.

Özkaya, Y. (2008). 18. Yüsyllda Osmanl Toplumu. İstanbul: Yap1 Kredi Yayınları

Özkaya, Y. (2014). Osmanlı Imparatorluğu'nda Âyânlı. Ankara: TTK Yayınları.

Reyhan, C. (2000). Taşranın Osmanlı-Türk siyasal hayatına etkisi bir açılama modeli, Toplum ve Bilim, 83, 267-291.

Sakaoğlu, N. (1966). Çeşmi Cihan Amasra. İstanbul: Latin Matbaası.

Ricœur, P. ve Direk, Z. (2014). Hafiza, Tarih, Unutma: Paul Ricœur ile Söyleşi, Cogito, 79, 95-104.

Samancıoğlu, K. (1999). İktisat ve Ticaret Bakımından Bartın, 2. Baskı. Bartın: Bartın Belediye Başkanlığı ve Valiliği.

Sarıoğlu, M. (2001). Kent Tarihi Çalışmaları Üzerine Bazı Düşünceler, Kebikeç, 11, 333-343.

Sevük, İ. H. (2014). Yurttan Yąılar. Ankara: Ötüken Yayınları.

Tuğrul, S. (2014). AVM'li Hatırlama ve Unutma, Moment Dergi, 1(2), 16-33.

Tözün, T. 31.01.2011 http://www.tanertozun.com/yazi/ guncel/195-karusagi-konagi-hakkinda-yok-olan-hikayeler. html (Son Erişim: 11.02.2018)

Uslu, A. (2016). Hafıza ve Geçmişin Talebi Olarak Tarih Arasındaki Ayrım. Vira Verita e-Dergi, 3, 42-65.

Wertsch, J. V. (2015). Kolektif Bellek, P. Boyer ve J. V. Wertsch (Ed.) içinde, Zibinde ve Kültürde Bellek (Y. A. Dalar, Çev.) (s. 149-174). İstanbul: Türkiye İş Bankası Kültür Yayınları.

Zonguldak Ticaret ve Sanayi Odas1 (1933). Cumburiyetin On Yilnda Zonguldak ve Maden Kömürü Havz̧ası. Zonguldak: ZTSO. 


\section{Görüşmeciler (yaş, cinsiyet ve meslekleri)}

Görüşmeci I. 91, erkek, kaptan. Yaşayan son birkaç çektirme kaptanından biri.

Görüşmeci II. 72, erkek, emekli öğretmen.

Görüşmeci III. 67, kadın, ev hanımı

Görüşmeci IV. 65, erkek, emekli maden işçisi.

Görüşmeci V. 63, erkek, emekli öğretmen.

Görüşmeci VI. 94, erkek, emekli kaptan. Son çektirme kaptanlarından biri.

Görüşmeci VII. 87, erkek, emekli kaptan, son çektirme kaptanlarından biri.

Görüşmeci VIII. 46, erkek, akademisyen, kentin birkaç kuşak denizcilik yapmış ailelerinden birine mensup.

Görüşmeci IX, 60, erkek, yaşayan son çektirme kaptanlarından birinin oğlu.

Görüşmeci X, 62, kaptan, usta-çırak ilişkisiyle öğrendiği denizciliği sürdüren, çektirmelerde çalışmış olan bir Bartınlı, şimdi modern gemilerde kaptanlık yapmakta.

Görüşmeci XI. 86, ev kadını. Kentin seçkin ailelerinden birine mensuptur.

Görüşmeci XII. 67, erkek, emekli banka personeli,

Görüşmeci XIII. 60, erkek, esnaf, kent tarihi ve kültürüyle ilgili amatör araştırmalar yapmakta.

Görüşmeci XIV. 49, erkek, eğitimci.

Görüşmeci XV.45 erkek, taksi şoförü,

Görüşmeci XVI. 48, balıkçı ve tersane işçisi.

Görüşmeci XVII. 45, erkek, öğretmen, Bartın'ın merkez köylerinden birinde doğmuş ve orada yaşamaktadır.

Görüşmeci XVIII. 43, mühendis, Bartın denizcilik tarihiyle ilgili araştırmalar yapmaktadır.

Görüşmeci XIX. 62, mühendis, çeşitli dernek ve sivil toplum kuruluşlarında Bartın ve Amasra'nın tarihi, doğası ve kültürünün korunup tanıtılması için gönüllü çalışmalara katılmaktadır. 